\title{
Therapeutic Attributes of Endocannabinoid System against Neuro-Inflammatory Autoimmune Disorders
}

\author{
Ishtiaq Ahmed ${ }^{1,2, *,+} \mathbb{D}$, Saif Ur Rehman ${ }^{1,+}$, Shiva Shahmohamadnejad ${ }^{3} \mathbb{D}$, Muhammad Anjum Zia ${ }^{4}$, \\ Muhammad Ahmad ${ }^{5}$ (D), Muhammad Muzammal Saeed ${ }^{4}$, Zain Akram ${ }^{2}$ (D), Hafiz M. N. Iqbal ${ }^{6}$ \\ and Qingyou Liu ${ }^{1, *(D)}$
}

Citation: Ahmed, I.; Rehman, S.U.; Shahmohamadnejad, S.; Zia, M.A.; Ahmad, M.; Saeed, M.M.; Akram, Z.; Iqbal, H.M.N.; Liu, Q. Therapeutic Attributes of Endocannabinoid System against Neuro-Inflammatory Autoimmune Disorders. Molecules 2021, 26, 3389. https://doi.org/ $10.3390 /$ molecules 26113389

Academic Editors: Maria José Rodríguez-Lagunas and Malen Massot-Cladera

Received: 20 April 2021

Accepted: 29 May 2021

Published: 3 June 2021

Publisher's Note: MDPI stays neutral with regard to jurisdictional claims in published maps and institutional affiliations.

Copyright: (c) 2021 by the authors. Licensee MDPI, Basel, Switzerland. This article is an open access article distributed under the terms and conditions of the Creative Commons Attribution (CC BY) license (https:/ / creativecommons.org/licenses/by/ $4.0 /)$.
1 State Key Laboratory for Conservation and Utilization of Subtropical Agro-Bioresources, Guangxi University, Nanning 530005, China; saif_ali28@yahoo.com

2 School of Medical Science, Gold Coast Campus, Griffith University, Southport, QLD 4222, Australia; zain.akram@griffithuni.edu.au

3 Department of Clinical Biochemistry, School of medicine, Tehran University of Medical Sciences, Tehran 14176-13151, Iran; shiva_shahmohamadnejad@yahoo.com

4 Enzyme Biotechnology Laboratory, Department of Biochemistry, University of Agriculture, Faisalabad 38040, Pakistan; rmazia@hotmail.com (M.A.Z.); muzammalsaeed143@gmail.com (M.M.S.)

$5 \quad$ Faculty of Veterinary Sciences, Shaheed Benazir Bhutto University of Veterinary and Animal Sciences (SBBUVAS), Sakrand 67210, Pakistan; mahmad118@yahoo.com

6 Tecnologico de Monterrey, School of Engineering and Sciences, 64849 Monterrey, Mexico; hafiz.iqbal@tec.mx

* Correspondence: ishtiaq.ahmed@griffithuni.edu.au (I.A.); qyliu-gene@gxu.edu.cn (Q.L.)

+ These authors contributed equally to this work.

Abstract: In humans, various sites like cannabinoid receptors (CBR) having a binding affinity with cannabinoids are distributed on the surface of different cell types, where endocannabinoids (ECs) and derivatives of fatty acid can bind. The binding of these substance(s) triggers the activation of specific receptors required for various physiological functions, including pain sensation, memory, and appetite. The ECs and CBR perform multiple functions via the cannabinoid receptor $1\left(\mathrm{CB}_{1}\right)$; cannabinoid receptor $2\left(\mathrm{CB}_{2}\right)$, having a key effect in restraining neurotransmitters and the arrangement of cytokines. The role of cannabinoids in the immune system is illustrated because of their immunosuppressive characteristics. These characteristics include inhibition of leucocyte proliferation, $\mathrm{T}$ cells apoptosis, and induction of macrophages along with reduced pro-inflammatory cytokines secretion. The review seeks to discuss the functional relationship between the endocannabinoid system (ECS) and anti-tumor characteristics of cannabinoids in various cancers. The therapeutic potential of cannabinoids for cancer-both in vivo and in vitro clinical trials-has also been highlighted and reported to be effective in mice models in arthritis for the inflammation reduction, neuropathic pain, positive effect in multiple sclerosis and type- 1 diabetes mellitus, and found beneficial for treating in various cancers. In human models, such studies are limited; thereby, further research is indispensable in this field to get a conclusive outcome. Therefore, in autoimmune disorders, therapeutic cannabinoids can serve as promising immunosuppressive and anti-fibrotic agents.

Keywords: endocannabinoid system; $\mathrm{CB}_{1}$ and $\mathrm{CB}_{2}$ receptors; cannabis; cancer; immunosuppressive

\section{Introduction-Problem and Opportunities}

The endocannabinoid system (ECS) is composed of endocannabinoids (ECs), associated receptors of cannabinoid, and metabolizing enzymes. ECs are endogenous lipid-based retrograde neurotransmitters in a biological system. They are bound to cannabinoid receptors (CBR), and cannabinoid receptor proteins are expressed via the vertebrate central nervous system (CNS) and peripheral nervous system. Cannabinoids are known as a group of terpene phenolic compounds and found in the Cannabis sativa (marijuana plant). Commonly, three types of cannabinoids are identified: (i) phytocannabinoids observed distinctively in the Cannabis sativa plant, (ii) endogenous cannabinoids found in mammals 
(i.e., humans and animals), and (iii) laboratory-based cannabinoids (i.e., synthetic) [1-4]. Living organisms respond to complex stimuli, and an evolutionarily conserved form of ECS exists from plants to mammals. The cannabinoids (over 80) are produced from Cannabis sativa. Their broad-spectrum characterization classifies them as an assembly of substances with a substantial structural correlation with Delta-9-tetrahydrocannabinol $\left(\Delta^{9}-\mathrm{THC}\right)$ and binds to the CBR. Marijuana is a primary active component of Cannabis sativa, which has been found highly effective to treat wide-ranging syndrome in patients with cancers, AIDS, CNS disorders (i.e., multiple sclerosis). Moreover, glaucoma is also included in the list of treatments by those who believed in the medicinal aspects of marijuana [5-9]. The chemistry of these substances shows various classes of particular chemicals, such as the close structural similarity of classical cannabinoids to the $\Delta^{9}-\mathrm{THC}$, non-classical categorized cannabinoids, the aryl sulphonamides, the ECs related eicosanoids, the aminoalkylindoles, and the quinoles $[10,11]$. There are additional compounds not categorized into these standard classes due to specific physicochemical characteristics, even though those exhibit the binding affinity to $\mathrm{CBR}\left(\mathrm{CB}_{1}\right.$ and $\left.\mathrm{CB}_{2}\right)$. Multi-dimensional characterization of marijuana on their potential medical effects can be selected during the evaluation parameters of marijuana and cannabinoids concurrence of specific human diseases, with fewer side effects. In the previous decades, the endocannabinoid pathway and the physiological impacts of cannabinoids have been studied extensively. Cannabinoids exhibit immunomodulatory effects, and their application, along with prospective roles as an autoimmune or inflammatory therapy, has widely been explored [12].

This review comprises the immunomodulatory and therapeutic potential of the ECS against different autoimmune disorders and other disease conditions, emphasizing cancer treatments and their biomedical perspectives in the 21st century. Particularly, we focused on organizing the research studies of ECs as promising treatment options for multiple sclerosis, type-1 diabetes mellitus, anti-inflammatory, and anti-fibrotic agents, rheumatoid arthritis (RA), and ameliorating neuropathic pains. The effective utility of practical therapeutics against cancer and tumor conditions has also been explained in later sections. The compilation of this updated information will be useful for medical researchers and professionals, pharmacists, and research scholars for designing and developing effective drug(s) strategies and biomedicines to counter various present-day human diseases and disorders.

\section{The Endocannabinoid System}

An ECS comprises endogenous ligands, associated $\mathrm{CBR}$ (particularly $\mathrm{CB}_{1}$ and $\mathrm{CB}_{2}$ ), and metabolic enzymes. Endocannabinoid receptors were named $C B R$ after the recognition of endogenous ligands. The ECs are obtained from the membrane that is composed of phospholipids. Therefore, they are known as bioactive lipid mediators. After the identification of the first lipid mediator, arachidonoyl-ethanolamide (AEA) of the ECS, (also known as anandamide) [13-15], different biomolecules associated with this family were discovered. The most vital molecules are 2-arachidonoyl-glycerol (2AG) and its isomer 1AG among monoacyl-glycerols; palmitoyl-ethanolamide (PEA); oleyl-ethanolamide (OEA), and the N-acyl-ethanolamides [16-18]. The cannabinoid receptor type- 1 and type-2, both $2 \mathrm{AG}$ and AEA are engaged in different biological functions; however, the AEA metabolism and attachment of the peroxisome proliferator-activated receptor- $\alpha$ is influenced by PEA and OEA [8,19-23]. These all biomolecules are explained in detail in the endocannabinoid related compounds. Partial or full agonists of $\mathrm{CB}_{1}$ receptors in terms of anandamide depend on tissue and biological response type. However, $\mathrm{CB}_{2}$ receptors can attach but have an intermittent effect and can perform like an antagonist $[19,20,24]$.

\subsection{Cannabinoids Receptor Agonists}

Cannabinoids receptors can be classified into four groups based on different chemical structures named as (i) classical (ii) non-classical (iii) aminoalkylindole (AAIs), and (iv) eicosanoid compounds. These groups are mostly heterogeneous $[16,17]$. The phytocannabinoids $\left(\Delta^{9}-\mathrm{THC}, \Delta^{8}\right.$-THC, cannabinol) and associated analogs (i.e., synthetic) form the 
classical group. O-arachidonoylethanolamine (virodhamine), arachidonoylethanolamide (anandamide), 2-Arachidonoyl Glycerol (2-AG), and other anandamide associated synthetic analogs/derivatives are present in the eicosanoid group. A cellular system of an organism usually produces the majority of ECs found in the eicosanoid group. Non-classical and AAIs groups contain synthetic cannabinoids. Both $\mathrm{CB}_{1}$ and $\mathrm{CB}_{2}$ receptors are the chief receptors of the ECS, and each of them possesses a different affinity of endocannabinoid agonists. For instance, the $\mathrm{CB}_{1}$ receptor has a greater affinity of $\Delta^{9}-\mathrm{THC}$, and without selective marking of $\mathrm{CB}_{1} / \mathrm{CB}_{2}$ receptor(s), the phytocannabinoid cannabinol possesses partial affinity (Figure 1) [24].

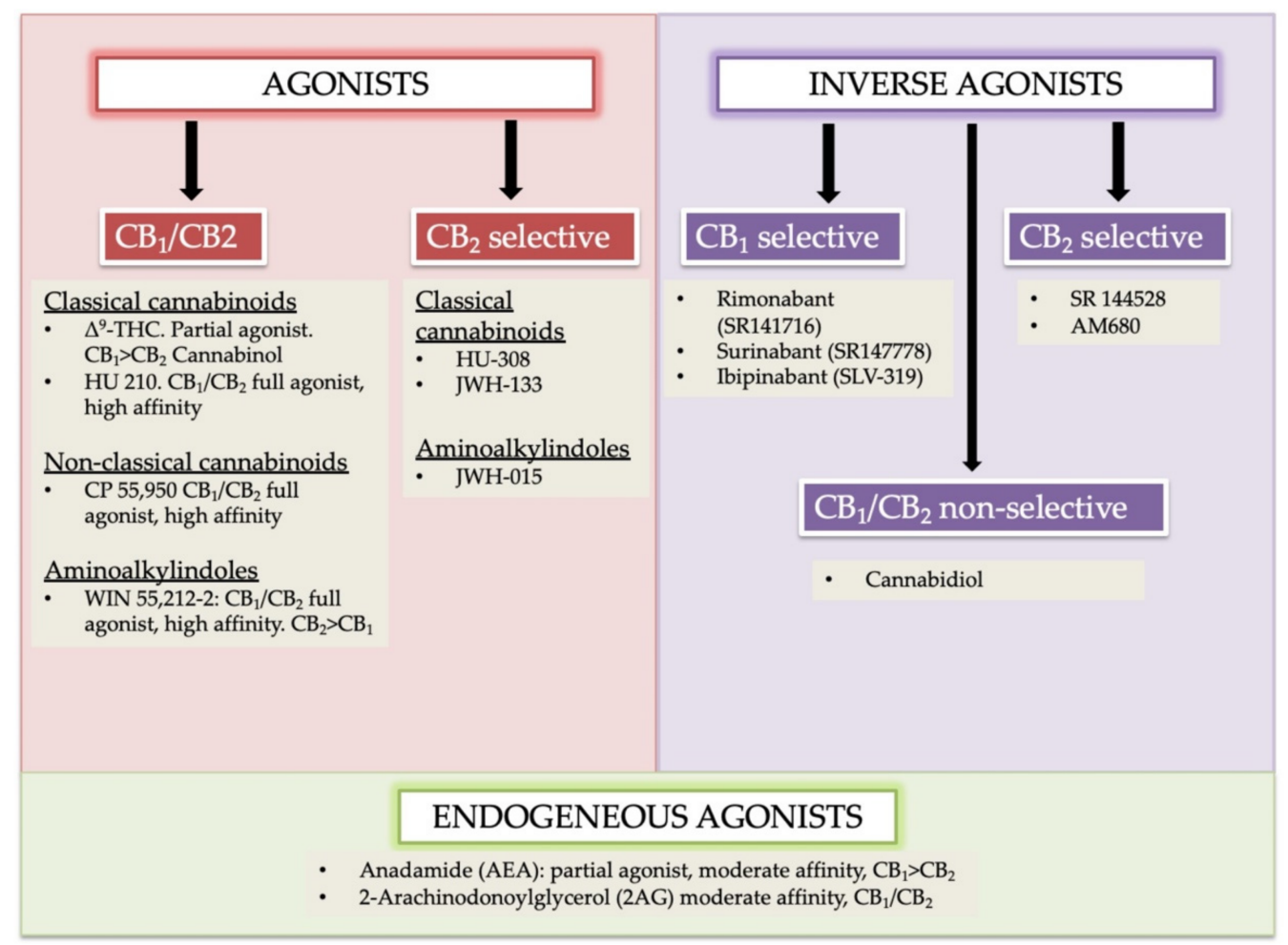

Figure 1. Agonists, antagonists, and endogenous agonist cannabinoids and their sub-types. Endogenous agonists: AEA and 2-AG; Exogenous agonist $\Delta 9$-tetrahydrocannabinol $\left(\Delta^{9}-\mathrm{THC}\right)$. The key psychoactive cannabis module, synthetic derivatives, HU 210, HU 308, CP 55,940 are identified. These compounds are commonly used as pharmacologic tools. Modified and reprinted from Ref. [24] with permission from Elsevier. License Number: 5066110366934. Abbreviation: $\mathrm{CB}_{1}$ (cannabinoid receptor 1); $\mathrm{CB}_{2}$ (cannabinoid receptor 2); HU-210, (highly potent cannabinoid receptor agonist); JWH-015 (a selective CB2 agonist); JWH-133 (a potent selective CB2 agonist); SR141716 (Rimonabant, a selective CB1 receptor antagonist or an inverse agonist); SR141716 (Rimonabant, a selective CB1 receptor antagonist or an inverse agonist); HU-308 (cannabidiol (CBD)-derivative drug); SLV 319 (a potent and selective CB1 receptor antagonist); CP 55,950 (a synthetic cannabinoid).

\subsection{Cannabinoids Receptors $C B_{1}$ and $C B_{2}$ and Functional Pathway}

Recognized $\mathrm{CBR}_{\mathrm{CB}}$ and $\mathrm{CB}_{2}$ belong to the structural membrane receptors and family of $\mathrm{G}$ protein-coupled receptors. They also have seven transmembrane spanning domains. Limiting cellular response towards the specific cannabinoid receptor ligands, the effect of partial agonism is variable from its binding, and thereby inverse agonism to its functional selectivity plays a crucial role [25]. The functional influence of both $\mathrm{CB}_{1}$ and $\mathrm{CB}_{2}$ receptors is acquired when heterotrimeric $\mathrm{G}_{\mathrm{i} / \mathrm{o}}$ (a subunit of $\mathrm{G}$ protein) proteins are coupled. However, the activated $\mathrm{CB}_{1}$ receptors perform their functions due to $\mathrm{G}$ alpha i/o activation [26]. The inhibition of the adenylate cyclase enzyme synthesis is due to the attachment of $\mathrm{CB}_{1}$ to its agonist. The binding of $\mathrm{CB}_{1}$ to its ligand decreases the levels of $\mathrm{CAMP}$ and the elevated 
level of mitogen-activated protein kinase (MAPKs). Moreover, in few cases, the activated $\mathrm{CB}_{1}$ receptor corresponding to $\mathrm{G}_{\mathrm{s}}$ proteins may accelerate adenylate cyclase cAMP [25-28].

In the cell membrane, both receptors (i.e., $\mathrm{CB}_{1}$ and $\mathrm{CB}_{2}$ ) and various ion channels, such as the potassium and calcium channels, are influenced positively because of independent activity. These ionic channels are activated when the cAMP-dependent interaction takes place between the molecules and the receptor. These molecules are recognized as protein kinase C, protein kinase A (PKA), p38, Raf-1, extracellular regulated kinase (ERK), $\mathrm{N}$-terminal kinase (JNK), and c-fos, c-Jun $[27,28]$. The $\mathrm{CB}_{1}$ activation causes the lowering of the $\mathrm{Ca}^{2+}$ ions entry in the cell, which is the key factor for releasing neurotransmitters without cAMP association and results in reduced secretions of neurotransmitters. Therefore, a pre-synaptic receptor $\left(\mathrm{CB}_{1}\right.$ receptor), when activated in a dose-dependent manner, leads to neurotransmitter release [29-31]. The regulation of the phosphorylation process and activation of various entities of the family of MAPKs, MAP kinase p38, and c-Jun can be performed through using both receptors. Consequently, JNK MAPK directs cell adhesion, proliferation, motility, and apoptosis. Glucose metabolism is also linked to gene expression [30,32-34]. Both receptors $\mathrm{CB}_{1}$ and $\mathrm{CB}_{2}$ that also respond via the stimulation of their agonists (exogenous/endogenous/synthetic). Agonist molecules are instantly deactivated when transported/uptake into cells, followed by their release and metabolic function. Both anandamide and 2-AG perform metabolism due to their enzymatic hydrolysis characteristics, and this process is carried out in combined activity of fatty acid amide hydrolase enzyme (FAAH) [35,36]. Furthermore, additional metabolic activities require monoglyceride lipase for the hydrolysis of 2-AG $[37,38]$. Figure 2 illustrates the summary of potential mechanisms of action [24].

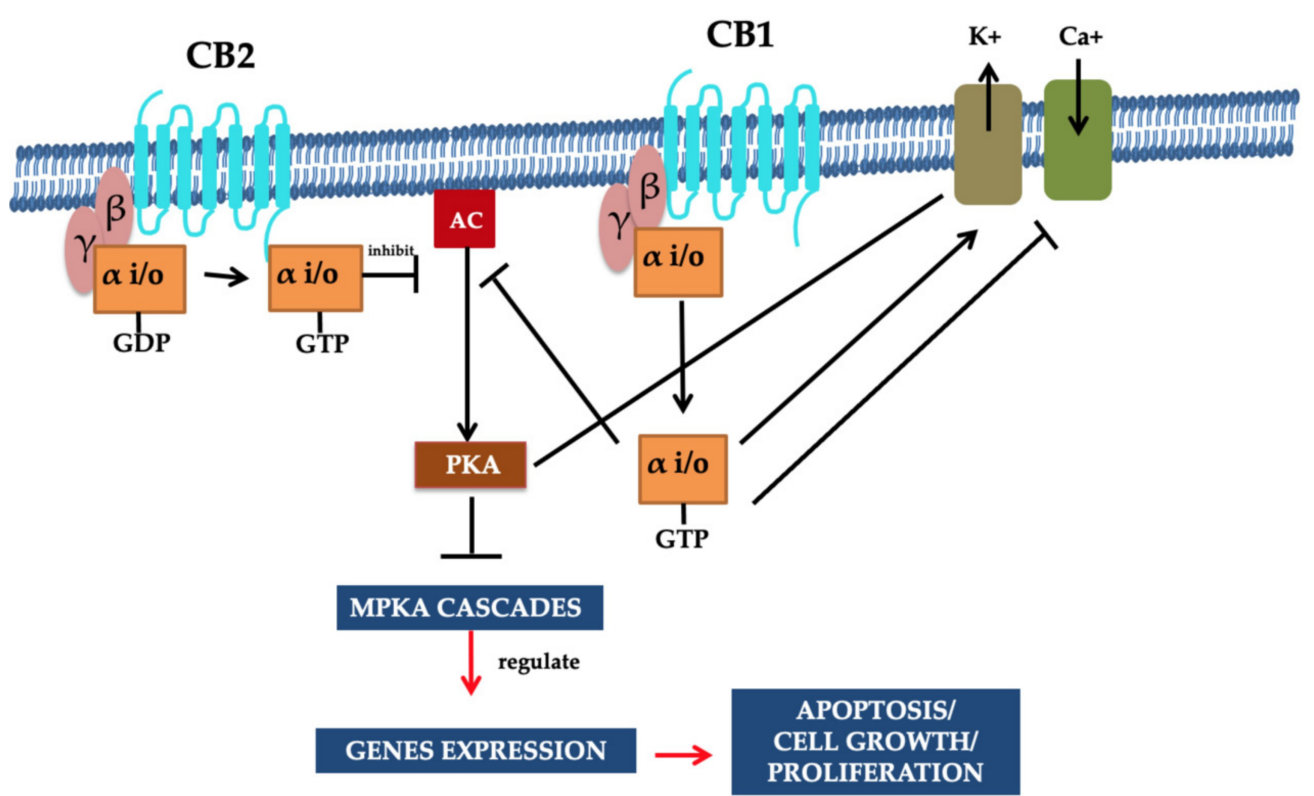

Figure 2. Signaling pathways of $C_{1}$ and $C_{2}$ receptors. $G$ proteins are associated with $C B R$ (i.e., $\mathrm{CB}_{1}$ and $\mathrm{CB}_{2}$ ). The inhibition of adenylyl cyclase activity and the stimulation of the variant MAPK cascades were demonstrated through these receptors' activation. Moreover, the $\mathrm{CB}_{1}$ cannabinoid receptor facilitates the regulation of the voltage gated $\mathrm{Ca}^{2+}$ channels as they are negatively regulated, and inwardly resolving $\mathrm{K}^{+}$channels are positively regulated. Intracellular free $\mathrm{Ca}^{2+}$ increase is prompted through phospholipase C (PLC) activation. The inhibition of gene expression is facilitated by the PKA, and reduction in CAMP directs cannabinoid-mediated inhibition. It is resulting in the MAPK cascade activation associated with cell survival or apoptosis. Such signaling pathways/mechanisms are associated with the multiple functions of the cells that are regulated through CBR. Reprinted from Ref. [24] with permission from Elsevier. License Number: 5066110366934. 
In addition to a few non-neuronal cells, central and peripheral neurons defined $\mathrm{CB}_{1}$ receptors $[8,39]$. The heterogeneous distribution of $\mathrm{CB}_{1}$ receptors is found among the $\mathrm{CNS}$ that aid the functional activities. Mainly all the functional activities controlling parts of the brain such as the cerebral cortex, entopeduncular nucleus, substantia nigrapars reticulate, hippocampus, caudate putamen, globuspallidus, cerebellum, and other areas of the brain and spinal cord possess the dense distribution $\mathrm{CB}_{1}$ receptors. The presence of $\mathrm{CB}_{1}$ receptors helps in processing or controlling the nociceptive information. Agonists' ability associated with the $\mathrm{CB}_{1}$ receptor could be categorized using the distribution pattern of $\mathrm{CB}_{1}$ receptor among the CNS to impair cognition memory. Moreover, their potential role in changing the motor function and the development of an anti-nociception are also studied [40-44]. The terminal end of the central and peripheral nerves contains few $C_{1}$ receptors and is involved in controlling the release of excitatory and inhibitory neurotransmitters [8,45]. Primarily $\mathrm{CB}_{2}$ receptors found on immune cells are well-characterized and play a key role in immunomodulation [37,46,47]. Chemical messengers releasing capability is shared between $\mathrm{CB}_{1}$ and $\mathrm{CB}_{2}$ receptors. Initially, at the $C N S$, cannabinoids act with multiple neurotransmitters and participate in the modulation of their release through the function of the $\mathrm{CB}_{1}$ receptor $[48,49]$ (Figure 3). Secondly, inflammatory cytokines release, and the immune system regulation require the prospective activity of $\mathrm{CB}_{2}$ receptors. In the following section, we have highlighted other types of CBR belonging to the ECS.

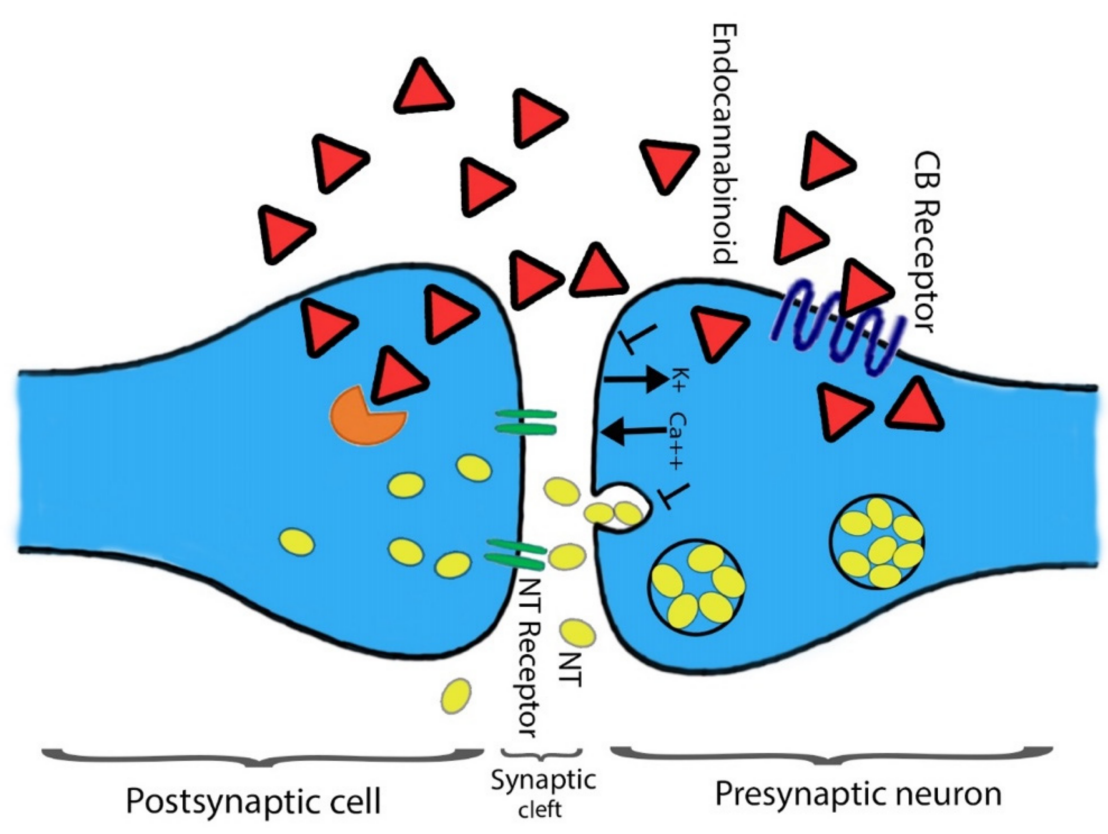

Figure 3. The action(s) of cannabinoids at the site of the presynaptic terminal. Agonists of a cannabinoid such as THC, 2-AG, and AEA attach to the $\mathrm{CB}_{1}$ receptor. The attachment is prompting alteration in intracellular levels of $\mathrm{Ca}^{2+}$ and $\mathrm{K}^{+}$ions. Consequently, direct towards secretion of neurotransmitter blockage at the site of presynaptic neurons. At the postsynaptic neuron site, cannabinoids are devastated through the FAAH enzyme, and the respective metabolites are reused. Shapes representation: Red triangle for endocannabinoid; yellow oval spots for neurotransmitters; Orange color shape represents FAAH.

\section{The ECS Associated Other CBR}

\subsection{Vanilloid Receptors}

The cannabinoids receptors-except for $\mathrm{CB}_{1} / \mathrm{CB}_{2}$, such as transient receptor potential cation channel subfamily V member 1 (TRVP1) — can have the ability to bind with cannabinoids receptors. TRVP1 is also known as the capsaicin receptor. In tissues (e.g., skin, blood vessels, heart, lung) and sensory neurons, it exists as a non-selective cation channel. In the peripheral nervous system associated with nociceptive neurons, mainly TRPV1 receptors 
are available; however, other CNS tissues also have TRPV1 receptors. Primarily, TRPV1 in afferent sensory and perivascular neurons is involved in transmitting and modulating pain (nociception) [50,51]. Moreover, the activation of afferent and perivascular neurons, and the TRPV1 activation using the endogenous cannabinoid receptor ligand anandamide facilitates the release of calcitonin gene-related and Substance P. Adverse effects such as proinflammatory, allogenic, and local vasodilatory were observed, although some advantages are also associated, such as anti-hypertensive and cardio protection [52,53].

\subsection{Other Receptors}

Various experimental studies verified that biotic factors for different cannabinoids are not directly associated with $\mathrm{CB}_{1} / \mathrm{CB}_{2}$ antagonists. In cannabinoid signal transduction receptor pathways, G-protein receptor 55 (GPR55) along with nicotine, the peroxisome proliferator-activated receptors (PPARs), 5-HT3, and adenosine A2A receptors are involved $[21,54,55]$. Experimental evidence presents the availability of allosteric sites on non-CBR apart from other receptors, (many but not all) for the binding of anandamide and some cannabinoids [8,56], like 5-HT2 receptors [57], 5-HT3 receptors [57,58], M1 and M4 muscarinic receptors, $\alpha 1$-adrenoceptors [59], as well as $\alpha$-amino-3-hydroxy-5-methy-4isoxazolepropionic acid, glutamate receptors (i.e., GLUA1 and GLUA3) [60]. Exploring the potential significance of allosteric sites (partially or fully) on the M1 and M4 receptors or 5-HT2 receptors requires more experimental research approaches [61,62].

\section{Role of STAT Protein and Cannabinoids}

In in vivo and in vitro experimental models, cannabinoids have been utilized in different anti-inflammatory activities and play an important role in diseases related to inflammatory degeneration, although the exact mechanism of action still requires more investigations [63] for the signaling pathways of cannabinoids involved in the anti-inflammatory functions. Studies illustrated the effect of various genes expression that is thought to be involved in inflammation reactions. Therefore, an induced inflammatory response is determined using the lipopolysaccharide (LPS) and microglial cell line of BV-2 mouse [64-66]. Consequently, along with marijuana, two major cannabinoids exist, THC and cannabidiol (CBD). These cannabinoids inhibit the synthesis and release of pro-inflammatory cytokines from LPS-activated microglial cells comprising interleukin- 6 , interleukin- $1 \beta$, and interferon $\beta$ (IFN $\beta$ ) [67]. CBR (i.e., $\mathrm{CB}_{1}$ and $\mathrm{CB}_{2}$ ) or the abn-CBD-sensitive receptors do not actively participate in anti-inflammatory reactions. Moreover, the THC and CBD both act, using partially overlapping mechanisms [64,68].

NF-kB pathway is important to facilitate the regulation of the pro-inflammatory gene expression. The up-regulation of the NF-kB pathway supports the activation of the STAT3 transcription factor (Signal Transducer and Activator of Transcription 3), an entity of homeostatic action that induces anti-inflammatory events [5,69]. For treatment, CBD involvement with THC (partially) resulted in a lower level of transcription of mRNA for the Socs3 gene. Socs3 gene is recognized as the down-regulator of STATs, particularly for STAT3 [70]. While activation of the LPS-induced STAT1 transcription factor is reduced using THC and CBD. The LPS-induced STAT1 transcription factor down-regulation is the key element of IFN $\beta$-dependent pro-inflammatory action [70]. Both THC and CBD possess diverse influences in pathways of the anti-inflammatory mechanism of action (e.g., IFN $\beta$-dependent and NF-kB pathways) $[69,71,72]$.

\section{Immune System and The Role of Cannabinoids}

Both $\mathrm{CB}_{1}$ and $\mathrm{CB}_{2}$ receptors are expressed in immune cells that are involved in the production of cannabinoids along with transports, release, and catabolic characteristics [21,73]. These immune cells include CD4 and CD8 leucocytes, B cells, NK (natural killer cells), monocytes, and neutrophils [74,75]. The range of expression of CBR depends on the state of cell activation and the stimulation and response of immune cells [73,76]. In an experimental mice model, the deficiency of FAAH increased the level of the anandamide in the CNS 
and periphery area [77]. Physiological involvement of ECs resulted in elevated levels of anandamide that mitigate the inflammatory activities and helps in reducing the immune system actions $[73,78]$. The results figured out that the ECS may potentially modulate the immune effects and proposed a theory that the exogenous cannabinoid involvement could have immunosuppressive effects. Therefore, it can lead to novel therapy development for diseases associated with inflammation and autoimmunity. Later on, many studies underpin the theory of this association $[73,79]$.

Furthermore, $\Delta^{9}$-THC can support the modulation of the Th1/Th2 balance by using the controlled immune actions of Th1 and the increasing level of Th2 [73,80]. However, $\Delta^{9}$-THC as a therapy recommendation is limited because of its psychoactive effects. Alternatively, cannabidiol possesses less affinity for both $\mathrm{CB}_{1}$ and $\mathrm{CB}_{2}$, resulting in null psychoactive effects $[8,81,82]$. Furthermore, some studies also proposed that the frequent administration of cannabidiol to humans does not have adverse side effects [83,84]. Primarily cannabinoids pretend their immunosuppressive features in four pathways: (1) apoptosis induction; (2) cell proliferation inhibition; (3) cytokines inhibition, and (4) production and induction of chemokine associated with regulatory T cells [85-87]. Among mitogeninduced human T lymphocyte and B lymphocyte (human neuroblastoma cells (CHP-100) and U937 lymphoma cell lines, respectively), anandamide induces dose-dependent apoptosis $[88,89]$. While $\Delta^{9}$-THC can trigger the apoptosis cycle (programmed cell death) in murine macrophages and T cells via regulating the activity of BCI-2 (B cell lymphoma-2), and also this cycle triggers by the action of caspases (cysteine-dependent aspartate-directed proteases, cysteine-aspartic proteases, cysteine aspartates) [90]. Because it is tough to detect the in vivo rate of apoptosis-as apoptotic cells are rapidly cleared through the pathway of phagocytes [91,92] - the induction of apoptosis by engaging the cannabinoids cannot be confirmed in in vivo results.

Non-activated lymphocytes are significantly affected by $\Delta^{9}-\mathrm{THC}$ as compared to activated lymphocytes. The cell line treated with THC exhibited more significant apoptosis levels compared to the cell line treated with both $\Delta^{9}$-THC and mitogen [92,93]. The expression of $\mathrm{CB}_{2}$ is down-regulated by the activated lymphocytes, which decreased the sensitivity towards $\Delta^{9}$-THC. In lymphocytes, induced thymocytes apoptosis is inhibited through $\Delta^{9}$-THC via administrating the $\mathrm{CB}_{2}$ antagonists. However, $\mathrm{CB}_{1}$ antagonists showed non-significant effects. Therefore, $\Delta^{9}$-THC performs function through $\mathrm{CB}_{2}$ receptors to induce apoptosis [94]. In a dose-dependent approach, cannabidiol induces apoptosis on $\mathrm{CD}^{4+}$ and $\mathrm{CD}^{8+} \mathrm{T}$ cells. Cannabidiol facilitates the production of reactive oxygen species (ROS), and the activation of caspase- 8 and caspase- 3 during apoptosis [95]. In vitro studies in both humans and mice showed that the increased and decreased concentrations of $\Delta^{9}$-THC stimulate the T cells and inhibit responses to the LPS, anti-CD3 antibody, and T cell mitogens [96]. A study demonstrates the two-phase action of cannabinoids on B cells: Firstly, increased proliferation of the B cell in response to $\Delta^{9}-\mathrm{THC}$, and secondly, inhibited B cells response to LPS after the administration of cannabinoid [96,97]. In other experimental models, $\Delta^{9}$-THC played a role in suppressing immune functions and increased the chances of infections. The exact pathway which is adopted to suppress the immunity by $\Delta^{9}-\mathrm{THC}$ is not yet fully understood. The earlier study illustrates that the induced inhibition of lymphocyte proliferation can be directly achieved on the immune cells instead of $C_{1}$ and $C_{2}$ receptors modulation. However, this activity was detected in the subsistence of antagonists of $\mathrm{CB}_{1}$ and $\mathrm{CB}_{2}$ [91]. The proliferation of thymocytes restrained through $\Delta^{9}-\mathrm{THC}$ because of the inhibition of calcium stabilization within the cell $[98,99]$. The inhibited proliferation of T lymphocyte and B lymphocyte was achieved in response to mitogen stimulation, and decreased the concentration of anandamide [100,101].

Cannabidiol inhibits the interleukin (IL1, IL12), tumor necrosis factor (TNF)- $\alpha$ interferongamma (INF- $\gamma$ ) cytokine secretion, and also the synthesis of Th2-associated cytokines through peripheral mononuclear blood cells [95]. The activity of prostaglandin E2 and tissue cyclooxygenase enzymes (COX) is restrained due to cannabidiol action. Low efficacy of $\Delta^{9}$-THC and cannabidiol supports the modification of TH1 immunity to protect TH2 immunity [91,96]. 
Cannabinoids may play a vital role in monocyte differentiation to macrophage phenotypes M1 or M2 and their capability to synthesize chemokines, cytokines, and the regulation of different mediators of the immune system [102-104].

Different people who commonly take cannabis are not responding differently to cannabinoids, particularly within the immune system. In exposed entities (non-naïve) to cannabis, a more than twice-a-week migration of monocyte may be inhibited via phytocannabinoids. In contrast, the entities (naïve) do not affect if not exposed in the last three years [105]. In a study, both ECs and synthetic cannabinoids had no adverse effects, and researchers demonstrated the association between these two. Cannabis (non-naïve entities) expressed a four-fold increased concentration of $\mathrm{mRNA}$ of $\mathrm{CB}_{1}$ receptor than naïve entities of cannabis, although the mRNA of the $\mathrm{CB}_{2}$ receptor remained the same. Therefore, the sensitivity of isolated monocytes from non-naïve entities correlates to the increased expression of $\mathrm{CB}_{1}$ receptors [8]. In Legionella pneumophila (Lp) infected dendritic cells, $\Delta^{9}$-THC possessed immunosuppressive effects. Immunization potential was restrained in Lp loaded cells in the pretreated (with $\Delta^{9}$-THC) dendritic cells in mice. In a ConA induced hepatitis model, liver damage is increased due to $\Delta^{9}$-THC, elevating levels of apoptosis within activated $\mathrm{T}$ cells, and the induction of $\mathrm{T}$ reg cells to inhibit the induced cytokines in vivo [87]. It is recommended that $\mathrm{T}$ reg cells can resist inducing the apoptosis via $\Delta^{9}$ THC and control the T cell activation which escapes from apoptosis [87,106]. Cannabis, particularly cannabinoid receptor ligands, help in the suppression of serum immunoglobulin (Ig) levels [107,108]. Decreased B cell count was identified via $\Delta^{9}-\mathrm{THC}$, including IgG, and IgM levels were also reduced [109]. There is a difference in opinion that exists about the level of B cell [110]. In mouse peritoneal macrophages, the spreading, phagocytosis, cytosis, the production of cytokine, and presentation of the antigen are suppressed through cannabinoid receptor ligands in vivo. However, in vitro studies showed the suppressed actions NK cells and cytotoxic effector [111].

Despite the entire discussion, few studies recommend that cannabinoids might have pro-inflammatory effects [112,113]: allergic responses [114]; $\mathrm{CB}_{1}$ receptors secreted mast cells inflammatory mediators [113], as well as the elevated proliferation of B cells [115]. Understanding the potential role of cannabinoids in the immunomodulation function is key. The subsequent factors are dependent on the types of cannabinoids, cell type, and the administrated concentration. Within immune cells, the optimal dose of cannabinoids leads to induced apoptosis that enhances the inflammatory actions and shields the host from acute and chronic inflammation responses. Therefore, they can be beneficial if the suppression of immune response is required. Additional clinical research is required to validate such studies in human entities [116-118].

\section{Autoimmune Disorders and Cannabinoids}

\subsection{Multiple Sclerosis (MS) and Cannabinoids}

Multiple sclerosis is recognized as a human CNS chronic neuro-inflammatory autoimmune demyelination disease. The $\mathrm{T}$ lymphocytes enable multiple sclerosis. The inflammatory process responds when the disruption of BBB leads the cause of inflammation, macrophages activation, and synthesis of cytokines and "cytotoxic" proteins like metalloproteinases. In an experimental mice model of multiple sclerosis (EAE (experimental autoimmune encephalomyelitis)), it was reported that $\mathrm{CB}_{1}$ receptors perform a primary function in administering neuro-inflammation. Mice deficient in a $C_{1}$ receptor sustain inflammation, and excitotoxic effects create substantial neuro-degeneration, consequently influencing the immune system $[119,120]$. In an EAE model, neuro-degeneration inhibition has been regulated by mediating THC. Thus, the reduction of inflammatory cytokines within cerebrospinal fluid and the associated level of glutamate was observed [121]. In the cerebral cortex, glutamate is the primary excitatory neurotransmitter. When it releases at increased levels, it can be associated with neurodegenerative disease(s). In the $\mathrm{CB}_{1}$ receptor knockout mice studies, increased susceptibility to neuro-filament damage, caspase 3 activation, and huge neuro-filament $\mathrm{H}$ epitope dephosphorylation during chronic replacing EAE 
were considered markers of axonal injury. The signaling pathway associated with the $\mathrm{CB}_{1}$ receptor suggests neuroprotection using the EAE involvement [122].

The $\mathrm{CB}_{1}$ receptor mediates down regulatory responses in the CNS. Human tested models administered with CB1 agonists showed improvement in motor disorders such as spasticity, tremor, and ataxia $[119,120]$. Rolipram is a well-recognized phosphodiesterase-4 inhibitor developed in the last decade of the 20th century as a potential antidepressant. Different types of rolipram inhibit EAE to reduce the clinical ineffectiveness of reduced motor inhibition. Basal ganglia normalization in EAE rats is also associated with the $\mathrm{CB}_{1}$ gene expression $[123,124]$. In EAE rats, endocannabinoid concentration was categorized based on levels of anandamide and 2-AG in motor-linked areas of the brain. Mainly, motorlinked regions of the brain include the striatum, midbrain, and other brain regions [125]. $\mathrm{CB}_{2}$-selective agonists (i.e., RWJ400065) do not exhibit the inhibition of spasticity. During $\mathrm{EAE}$ in the $\mathrm{CNS}, \mathrm{CB}_{2}$-deficient $\mathrm{T}$ lymphocytes perform restricted levels of apoptosis, elevate rated proliferation, and massive synthesis of inflammatory cytokines that result in lethal clinical disease(s). Furthermore, $\mathrm{CB}_{1}, \mathrm{CB}_{2}$, and $\mathrm{FAAH}$ selective glial expression have been categorized in association with multiple sclerosis. In the pathogenesis of the current disease, these components have supporting roles for the ECS [126].

During endogenous cannabinoid MS progression, anandamide performs an essential role in administrating the inflammation process. Selective anandamide treatment using an inhibitor (UCM707) demonstrated that there is a minor progression in motor function and reduced microglial activation during established disease. UCM707 can reduce the expression of MHC class II antigen, decrease the cellular infiltrates, and synthesize proinflammatory cytokines (i.e., TNF- $\alpha$, IL-1 $\beta$, IL-6) in the spinal cord. In CNS inflammation conditions, the highly activated ECS protects neurons by anandamide from inflammatory damage via the $\mathrm{CB}_{1} / \mathrm{CB}_{2}$-mediated rapid induction of mkp-1 microglial (mitogen-activated protein kinase phosphate-1) [127]. Although infrequent data is available in human models, a clinical trial resulted in the effect of $\Delta^{9}$-THC being administered in a group of patients (i.e., $\sim 498$ ) along with initial or secondary stage multiple sclerosis. There were no significant variations recorded in all associated trials of the progression of MS. However, the clinical variation might have affected the potential progression rate lower than anticipated [126,128-130].

\subsection{Cannabinoids in Rheumatoid Arthritis}

Inflammatory and degenerative joint diseases are pathologically characterized or associated with the loss of articular cartilage. There is an elevated cartilage breakdown in osteoarthritis and RA. This is induced by adopting the progressive synthesis of inflammatory cytokines, particularly IL-1, and synthesis of TNF through the synovium cells or articular chondrocytes [131-133]. Previous studies suggested an increase in specific matrix metalloproteinases (MMP-3 and MMP-13) are responsible for destroying cartilage. In animal models of arthritis, cannabinoids demonstrated anti-inflammatory effects and reduced damage of the joint [134,135]. In vitro studies proposed that cannabinoids restrain the synthesis of a cytokine through RA fibroblast. Furthermore, matrix metalloproteinases (MMPs) are secreted from fibroblasts as synovial cells [131,136]. Interleukin 1(IL-1) reduction leads to the induction of proteoglycan and degradation of collagen within bovine cartilage that consequently limits the breakdown of extracellular cartilage matrix mediated by cannabinoids [137].

Synthetic cannabinoid(s) [i.e., WIN-55,212-2] are agonists of both receptors, such as $\mathrm{CB}_{1}$ and $\mathrm{CB}_{2}$, and these can activate different receptors, including proliferator-activated alpha and gamma (PPAR $\alpha$ and $\gamma$ ) receptors of peroxisome [138-140]. The MMP-3 and MMP-13 protein(s) gene expression can be reduced using the synthetic cannabinoid WIN$55,212-2$ during IL-1b availability. It signifies that cannabinoid might perform better function(s) in the case of arthritis therapy. Moreover, gene expression of tissue inhibitors of matrix metalloproteinases (i.e., TIMP-1 and TIMP-2) substantially reduces it to below basal levels $[141,142]$. In vitro studies were organized to check the efficacy of $C_{2} R$ agonist [HU-308 (Hebrew University-308), an agonist for peripheral cannabinoid receptor $\mathrm{CB}_{2}$ ] and 
IL-1 $\beta$-induced proliferation (e.g., fibroblast-like synoviocytes) was inhibited in pretreated cultured RA fibroblast with an agonist HU-308.

The synthesis of pro-inflammatory cytokines (particularly IL-6) and matrix metalloproteinases (MMP3 and MMP13) are decreased by the associated agonist and were linked with cartilage destruction. Another report represented that non-psychoactive cannabinoid ajulemic acid (AJA) reduced the secretion of matrix metalloproteinases (i.e., MMP-1, MMP-3, and MMP-9) from fibroblast. Therefore, IL-1a plus TNF- $\alpha$ activated synovial cells $[143,144]$. An in vivo work reported that AJA expression responds to the declining level of Adjuvant-induced arthritis [145]. In the mouse model for arthritis study, the synthesis of TNF mouse macrophages was inhibited in response to the administration of a new synthetic cannabinoid HU-320 (Hebrew University-320). The researcher observed significantly reduced reactive oxygen intermediates and a rise in the level of serum TNF suppression $[141,142]$. These experimental studies recommended the potential antiinflammatory characteristics of cannabinoids and proposed their use to treat inflammatory arthritis. It is confirmed that the use of cannabinoids in human RA reduced inflammation. However, other reports pretend the role of cannabinoids in the therapy of pain was associated with RA. A significant primary role of the ECS is performed in the peripheral regulation of nociception $[143,144]$. Nociceptor terminals are available on $\mathrm{CB}_{1} \mathrm{R}$ that may exhibit anti-nociceptive and anti-inflammatory functions of contiguous synthesized $\mathrm{N}$ arachidonoyl ethanolamine. In addition, they performed the inhibitory effect(s) on the secretion of excitatory neuropeptides $[8,146]$.

$\mathrm{CB}_{1} \mathrm{R}$ and $\mathrm{CB}_{2} \mathrm{R}$ are distributed in the dorsal root ganglia, and their activation reduces the transmission of nociceptive [52,147]. The ECS administers nociception that is controlled by the $\mathrm{CB}_{1} \mathrm{R}$ available at the supraspinal and spinal stage [52,148]. According to pharmacological studies, peripheral endocannabinoid basal activity recommended the expression of nociceptor activity in osteoarthritic joints [149]. In synovial biopsies started from total knee arthroplasty of patients suffering from advanced RA and osteoarthritis, both mRNA and protein were presently associated with $C_{1} R$ and $C_{2} R$ [150]. In the synovial fluid of patients suffering from this disease, both anandamide (AEA) and 2-arachidonoylglycerol (2-AG) were identified, but no solid evidence was about the operational mechanism of the ECS in osteoarthritic joints [150]. In the rat model-based osteoarthritis studies, the level of spinal cord AEA, 2-AG, and their synthesizing enzymes were higher [151,152]. Briefly, these studies provide some preliminary basis regarding the involvement of the ECS during osteoarthritis disorder. However, few experiments were conducted using a human experimental model, and the available data does not provide smooth information because there are disagreements between different research groups. Very few research data are available about rheumatic diseases that show the effectiveness of cannabinoid nabiximol on chronic pain.

\subsection{Cannabinoids in Scleroderma}

In scleroderma fibroblasts, the overexpression of both $\mathrm{CBR}$ (i.e., $\mathrm{CB}_{1}$ and $\mathrm{CB}_{2}$ ) was carried out to compare with healthy and normal fibroblasts. The effect of agonist (WIN55,212-2) of both receptors was observed in the synthesis of the collagen. In the skin fibrosis study, inhibition of type-1 collagen and procollagen type-I PIP supernatant levels were detected. Supernatant levels of both types were directly linked with the changing concentration of both agonists (WIN55,212-2) [153-155]. The decrease in the growth factor contributed to the fibrosis process, TGF- $\beta$ and CTGF (a downstream mediator of TGF- $\beta$ ) adversely affected the synthesis of type- 1 collagen. Similar results were acquired in scleroderma pathogenesis that involved the fibroblast transdifferentiation inhibition and over-expression of IL-6 in scleroderma cultures $[32,156]$.

The agonist WIN55,212-2 raised a significant count of the scleroderma fibroblasts during apoptosis, and these results were found during the anti-proliferative effect of cannabinoids [157]. As a result, the toxic effect of WIN55,212-2 was not observed in cell cultures. However, the "classical" both $\mathrm{CBR}$ (i.e., $\mathrm{CB}_{1}$ and $\mathrm{CB}_{2}$ ) did not possess the anti- 
fibrogenic effect of WIN55,212-2 [158]. Further studies showed that signal transduction pathways of CBR may additionally consist of: (a), transient receptor potential vanilloid type-1 (TRPV1); (b), adenosine A2A receptors; (c), GPR55 and nicotine; (d), 5-HT3; (e), the peroxisome proliferator-activated receptors (PPARs) $[21,157,159]$. Oral administration of non-psychoactive synthetic analog/derivatives of tetra-hydrocannabinol (ajulemic acid (AjA)) has a binding affinity with PPAR- $\gamma$ (peroxisome proliferator-activated receptor- $\gamma$ ). This attachment inhibits the skin fibrosis development and decreases the thickness of skin approximately to the control stage. At the basic biological stage, a dose-dependent reduction of procollagen and 5TGF- $\beta$ was utilized $[157,160]$. It is also hypothesized that the stimulation of PPAR- $\gamma$ might possess an anti-fibrotic effect.

\subsection{Type-1 Diabetes and the Role of Cannabis}

Pancreatic $\beta$-cells in type- 1 diabetes mellitus are prone to damage through lymphocytes CD4Th1 and CD8T [161,162], including the preliminary laceration of this syndrome, leukocytes, specifically lymphocytes and the islets are infiltrated during insulitis type-1 diabetes mellitus [163]. The presence of diabetes was significantly controlled from $86 \%$ to $30 \%$ (in non-treated mice vs. treated mice with cannabidiol). The experimental study was conducted for six to twelve-week-old non-obese-diabetes (NOD), and cannabidiol treatment significantly reduced the plasma levels of INF- $\gamma$, TNF- $\alpha$, and other TH1 cytokines in experimental mice. Concurrently, the synthesis of IL4 and IL10 (TH2 cytokines) was increased. Histopathology investigations of pancreatic islets extracted from mice treated with cannabidiol revealed the subsequently reserved insulitis. However, key insulitis and associated TH1 cytokine can be delayed or inhibited using cannabinoids in the NOD mice model [64,161].

Cannabinoid might inhibit diabetes type-1 in NOD young mice (i.e., four-week-old). Later on, similar research was carried with eleven to fourteen weeks old NOD mice treated with cannabidiol. The occurrence of diabetes was increased at the end of the treatment from $86 \%$ to $100 \%$ in control non-treated mice. However, treated mice with cannabidiol only showed $32 \%$. Histological analysis revealed that cannabidiol treated mice pancreas exhibits more intact islets than in the control group mice [64,161]. Thus, Cannabidiol might have a potential primary function in the prevention mechanism of human type-1 diabetes. However, the mechanism of auto-immune characteristics of this molecule requires further investigation. It is important to study the deviation response of Th1 if it possesses the non-specific characteristics as an immunosuppressive agent. Cannabidiol is initiating the aberration when Th1 transforms into Th2. It is hypothesized that it might be recruited to prevent diabetes before the complete $\beta$-cells destruction in early on-set patients and maybe in high-risk patients. Before the destructive response of Th1, the auto-immune response is initiated to protect the response of Th2. Therefore, cannabidiol-based treatment is no longer needed, excluding the concern to more extended protection effects $[64,161]$. Alternatively, if there is a mechanism of non-specific immunosuppression, then it requires associated permanent therapy. Critical potential risks are linked with the extended therapy options, such as enhanced vulnerability to devious dangerous infections and the possibility of enhanced malignancy. Some risks are directly connected to diabetes; however, they can be controlled along with intensive therapy of insulin recommended based on glucose levels $[64,161]$. The type of therapy for other linked risks is essential to be carefully evaluated before applying human cannabinoid therapy.

The immune response of either single or both Th1 or Th2, cytokines mediates a critical immunomodulatory role, and macrophages secrete cytokines [164]. In the macrophagedepleted NOD mice model, the IL-12 administration is recognized as a potential cause of the disease [64]. However, the synthesis of IL-2 macrophage was significantly reduced by the cannabidiol [165]. The reduction of IL-2 triggers the TH2 discrepancy along with reduced INF-g synthesis. Enhanced IL-12 effects stimulated the cytotoxic T cells, synthesis of TNF- $\alpha$ by macrophages, IL-1, IL-6, and nitrogen-free radicals by INF- $\gamma$. These molecules are linked with the destruction of $\beta$-cells $[64,161]$. Subsequently, macrophage IL-2 synthesis might involve 
suppressing Th1-mediated auto-immunity $[78,166]$. Further studies are required to confirm if essentially Th1/Th2 shift within humans gives long-term protection from disease.

\subsection{Obesity and Endocannabinoids}

ECs have a considerable effect on the body mass index and take part in regulating glucose metabolism by mediating the lipophilic molecules $[167,168]$. The clinical trials recommended that peripheral $\mathrm{CB}_{1}$ receptors mediated glucose metabolism regulation and suggested that adiponectin levels, lipids, and glucose metabolism are affected when the $\mathrm{CB}_{1}$ receptor is blocked. As a result, the weight is lost $[167,169,170]$. The signaling pathway and synthesis of endocannabinoid(s) are commonly dependent on externally stimulated factors such as metabolic dysregulation, cellular stress, and damage of tissue(s) $[169,171]$. Although ECS regulation is directed to change in response to obesity, the peripheral organs or the brain region of the body in response to obesity or after a high-fat diet stimulate the ECS $[146,169,172]$. A potential mechanism of the activation of the ECS may consist of an increased level of fatty acids in the diet. This might be a possible pathway/mechanism; however, the FAAH reduced the degradation of enzymes in the liver in diet-induced obese mice [167]. Recently, it reported that obese post-menopausal women described the increased level of ECs, down-regulation of FAAH gene expression, and subcutaneous adipose $\mathrm{CB}_{1}$ [169]. Bluher et al. explained the significant changes in ECS regulation during obesity and highlighted the increased level of circulating ECs. The increased level of ECs is directly correlated to the visceral adipose tissues, and abdominal obesity associated with the ECS can treat metabolic changes as a primary target [173].

\subsection{Cannabis and Inflammatory Bowel Diseases}

Cannabis is crucial for the treatment of bowel inflammation. However, actual mechanisms are not yet fully described; possibly $\mathrm{CB}_{1}$ and $\mathrm{CB}_{2}$ can take in mild and acute conditions [5,174]. In the last decade, several animal model-based studies have determined the probable effects of cannabinoids for possible therapy in colitis (inner lining inflammation or inflammatory reaction inside the colon) conditions. Numerous studies have confirmed that cannabinoid agonists act as regulators in inflammatory response via the cannabinoid receptor $[174,175]$. In humans, distinct expression of IBD CBR performs regulatory roles of cannabinoid in the disease condition [176-179]. In ulcerative colitis (UC), anandamide and producing enzymes are decreased, and the expression of the $\mathrm{CB}_{2}$ receptor and associated enzymes are increased for the production and degradation of the 2-arachidonoylglycerol $[180,181]$. The ECS is activated during gut inflammation, although inflammation may be reduced through endogenous anandamide $[176,177,180-182]$ (Figure 4). Both receptors $\mathrm{CB}_{1}$ and $\mathrm{CB}_{2}$ are distributed at the colonic epithelium; therefore, a high level of cannabinoids might be involved in the wound closure in the colon epithelial $[176,183]$. The $\mathrm{CB}_{2}$ leads to apoptosis, and in colitis, it inhibits the proliferation of $\mathrm{T}$ cells and reduces the neutrophils utilization, followed by macrophages to the inflamed colon. In the enteric nervous system, the ECS may control the gut motility and the secretion(s) using the $\mathrm{CB}$ receptors $[5,64]$. During $I B D, \mathrm{CB}_{1}$ receptor(s) may protect the bowels from hyperstimulation. This mechanism facilitates THC-based IBD symptoms, primarily disease diarrhea; furthermore, it involves inflammation/inflammatory reactions [5,64]. Patients suffering from UC specifically stated that cannabis stimulates the recovery pathway from diarrhea. In the $C N S$, stimulation of the $\mathrm{CB}_{1}$ receptor decreases pain sensation and nausea. Moreover, peripherally restricted $\mathrm{CB}_{1}$ and $\mathrm{CB}_{2}$ agonist was too weak to enhance colitis, and these facts strengthened the proposed theory [180]. 


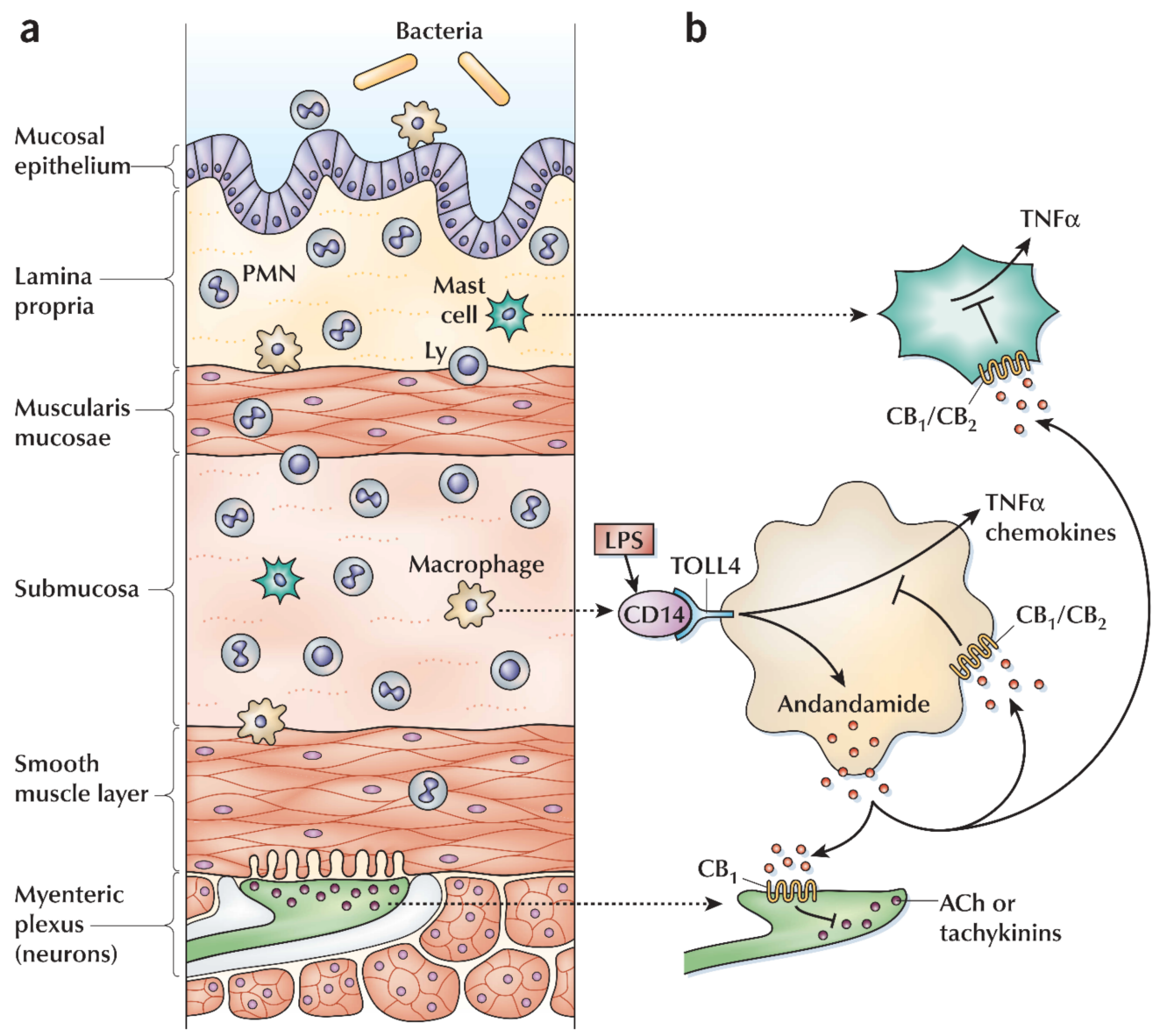

Figure 4. Anti-inflammatory ECs recommended targets and cell types in inflammatory bowel disease. (a), Inflamed bowel cross-section along with infiltration of the leukocytes (i.e., lymphocytes (Ly), polymorphonuclear leukocytes (PNM), macrophages, and mast cells). (b) In macrophages, the synthesis of the MIP-2 macrophage inflammatory protein-2 and CXCL- 8 (chemokines), TNF- $\alpha$ (Tumour necrosis factor $\alpha$ ), and anandamide initiated by LPS. Anandamide performs autocrine mediation to inhibit the synthesis of TNF- $\alpha$ and synthesis of the chemokine. The inhibition is carried out using receptors $\mathrm{CB}_{1}$ or $\mathrm{CB}_{2}$ (one of two or both). The activation of both receptors $\mathrm{CB}_{1}$ and $\mathrm{CB}_{2}$ can inhibit the synthesis pathway of TNF- $\alpha$ in mast cells. Consequently, inflammation reduction and leukocyte infiltration processes are affected. Stimulation of $\mathrm{CB}_{1}$ receptor paracrine on extrinsic and intrinsic enteric neurons blocks the release of acetylcholine (ACh) and tachykinin, respectively, that results in the inhibition of gut motility. The use of the FAAH inhibitor prevents the anandamide breakdown. Reprinted from Ref. [180] with permission from Springer Nature. License Number: 5066110580718. Abbreviation: CD14 (cluster of differentiation 14); TOLL4 (toll-like receptor 4 (TLR4)); LPS (lipopolysaccharide).

A placebo-controlled cohort study was conducted among 21 patients suffering from Crohn's disease [184]. In 50\% of patients, cannabis-induced clinical remission and $80 \%$ of the total patients did not respond to anti-TNF- $\alpha$, while in comparison to a placebocontrolled cohort study, only suggestive improvement occurred, with no induced remission. However, a declining trend was observed among participants when cannabis therapy was carried out. Another study conducted among patients with IBD (via cannabis) recorded that abdominal pain was enhanced [185]. Ref. [186] found that therapeutic cannabis was linked to the recovery process from Crohn's disease. Some patients suffering from UC and CD use cannabis for appetite enhancement [187]. A significant rise in the individual(s) weight was noticed as a result of using (i.e., ingesting) cannabis [188]. It can be hypothesized that cannabinoid therapies could have useful effects on IBD, although more trials are needed to recognize effective cannabinoid types, mode of intake, and the recommended dose [186]. 


\subsection{Thyroid Cancer}

In the thyroid gland, thyroid carcinoma is the most antagonistic form of cancer. Anaplastic thyroid carcinoma cell line (ARO) consists of an IL-12 gene with an antitumorigenic effect $[189,190]$. The anti-tumorigenic impact was noticed in response to the activation of the cannabinoid receptor. Different researches agreed that apoptosis activity is induced in cell lines $\mathrm{ARO}$ and $\mathrm{ARO} / \mathrm{IL}-12$ and $\mathrm{CB}_{2}$ agonist JWH-133 and $\mathrm{CB}_{1} / \mathrm{CB}_{2}$ agonist WIN-55,212-2 both facilitate the apoptosis [189,191]. In carcinoma cells of the thyroid, 2-methyl-2'-F-anandamide (Met-F-AEA) induced apoptosis, and the apoptosis pathway is mediated through p53 and p21 [192,193].

\subsection{Ovarian Cancer}

The ECS exists in CNS and peripheral areas of the body, and the study of sex steroid hormones validated these verdicts. The synthesis of progesterone steroid hormone C-21 occurred in the ovarian corpus luteum after ovulation that probably contributed to endocannabinoid signaling regulation. Human lymphocyte FAAH activity is upregulated by the expression of progesterone (via the transcription factor Ikaros) [194,195] that consequently reduced AEA levels in plasma [196]. This system controls various physiological roles and behavior of the cellular pathway, as presented in Figure 5 [196]. Moreover, in immortalized human lymphoma cells line (U937 cells), progesterone tends to increase the FAAH expression level and related activity. In contrast, the immortalized cell line of human neuroblastoma (CPH100 cells) did not possess these specific characteristics [196]. It has been reported to have an insignificant effect in lymphocytes on EMT (endocannabinoid membrane transporter), NAPE-PLD (N-acyl phosphatidylethanolamine phospholipase D), and $\mathrm{CB}_{1}$ expression [196]. The expression of uterine NAPE-PLD has been down-regulated in the mice model. The down-regulation of uterine NAPE-PLD modulates the reduction of AEA levels [197] in tissues and performs a function to down-regulate the FAAH activity in the uterus of a pregnant mouse $[194,195]$. However, when accounted for both together with a discreet expression of NAPE-PLD in mice, the FAAH ratio's activity can be significant to regulate AEA levels in the mouse uterus and thereby maintenance of pregnancy or pathologies of endometrial (uterine cancer). In brief, the progesterone action on AEA levels in the uterus of rats is more complicated when progesterone activates its synthesis in the ovariectomized animal $[194,195]$. All studies mentioned the ovarian hormones affect the synthesis of anandamide. The change in the physiological conditions significantly affects the performance of ovarian hormones. These physiological conditions may be dependent on activated blastocyst, estrous cycle, and early pregnancy. The exact feedback mechanisms associated with all these activities are not yet fully known, although a sheep model of experimental studies illustrated progesterone level, corpus luteum weight, mRNA ration concerning corpus luteum LH receptor, and LH receptor density [194,195]. In pregnant rats, the progesterone levels in serum and LH content participate in the administration of AEA levels [195]. Therefore, the co-regulation of ECs and progesterone function may be linked with positive and negative feedback mechanisms.

The $17 \beta$-oestradiol (E2) is known as the most effective growth stimulator form of estrogen. The E2 has a direct and/or indirect association with the ECS. Such E2 association assisted NAPE-PLD activation and the blocked FAAH production. It triggers endothelial cells to secrete AEA $[8,194,196]$. In comparison, another study revealed that estradiol downregulated the NAPE-PLD within the uterus, consequently reducing anandamide levels; however, this is not inveterate yet [198]. Some studies elaborated restrained activities of FAAH via E2 in mouse uterus, despite the regulatory fact of FAAH expression [194,195]. Moreover, estrogens appear to perform the regulation mechanism of the ECS in other types of cancers [195]. In sex steroid hormone-dependent tumors, the discrepancy of estrogen effects on the ECS signaling pathway depicted a complicated interaction that performs a critical role. In the following paragraph, we emphasized providing details of endometrial cancer. 


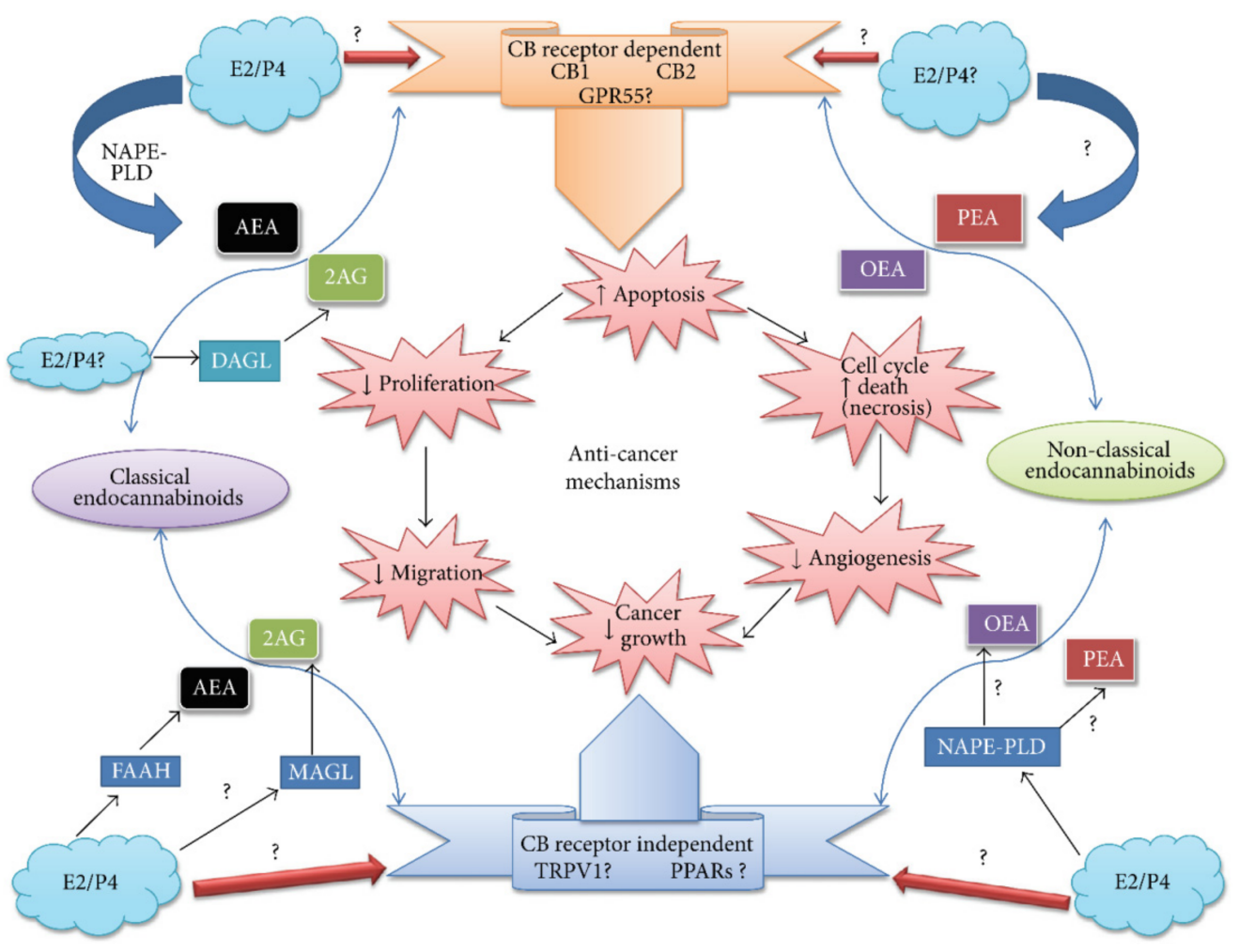

Figure 5. Putative collaborations between sex hormone-dependent cancers and the ECS (endocannabinoid system). The production of ECs is carried out by the actions of specific enzymes (light yellow boxes and broad blue arrows). These actions are supported by the enzymatic hydrolysis of NArPE lipid precursors, particularly associated with the membrane. Both sex steroid hormones perform theoretical roles in the pathway. Both hormones, such as progesterone (represented as P4 at each corner in the circle filled with light blue color) and oestradiol (represented as E2 at each corner in the circle filled with light blue color). 2-arachidonoylglycerol (2-AG) and anandamide ( $N$-arachidonoylethanolamide, AEA) are known as classical ECs. The non-classical ECs are recognized as PEA and OEA. Both forms of ECs (i.e., classical and non-classical) bind independently or in concert at receptors $\mathrm{CB}_{1}, \mathrm{CB}_{2}$, and GPR55. Receptors PPAR and TRPV1 (represented in gold cold fill boxes) involve in the anticancer mechanism. Green boxes show the important activities linked to the anticancer mechanism in the center of the figure. There are speculated observations; either all these activities are interconnected or perform functions independently. Although this mechanism significantly reduced the mass of cancer cells. The ECS and its adjusting boundaries with sex steroid hormones are represented in the anticancer mechanisms, though theoretical or unidentified associations are specified using a question mark(s). $\uparrow \downarrow$ Arrows illustrated the increasing or decreasing activity of a particular anticancer mechanism. Reprinted from Ref. [196] with permission under open access article distributed under the Creative Commons Attribution License. Abbreviation: NAPE-PLD (N-acyl phosphatidylethanolamine phospholipase D); OEA (oleoylethanolamide); PEA (palmitoylethanolamide); PPAR (peroxisome proliferator-activated receptor); TRPV1 (transient receptor potential vanilloid type-1); AEA (arachidonoylethanolamide); FAAH (fatty acid amide hydrolyse); MAGL (monoacylglycerol lipase); DAGL (diacylglycerol lipase).

Endometrial cancer is the seventh most commonly and globally diagnosed malignancy [199], and the fourth most commonly diagnosed gynecological cancer identified in the UK in 2008 [200]. Endometrial cancer refers to numerous forms of malignancies. These malignancies evolve from the endometrium, obesity, early menarche, null parity, late menopause, and estrogen-only hormone replacement-based therapy. These factors are potentially documented as high-risk factors that lead to endometrial carcinoma. More exposure to estrogen plays a crucial role in the etiology of endometrial cancer [201,202]. Menstrual disorders, obesity, and endometrial cancer are directly linked to chronic inflam- 
mation [201,202]. Additionally, endometrial cancer risk can be enhanced due to endometriosis and uterine fibroids because such malfunctions are linked with excess concentration of estrogen and pelvic inflammation [201,202]. Endometrial cancers are of two types based on clinical and molecular characteristics. The first type is estrogen-dependent endometrioid carcinomas (EECs), or type-I, and is observed in approximately $80 \%$ of the cases. Type- 1 expresses receptors linked to estrogen (ER) and progesterone (PR) biomolecules. Type-I is exhibited in premenopausal and postmenopausal young women [203,204] and strongly connected with unrestricted exposure, either exogenous or endogenous of estrogen. The second type is non-endometrioid endometrial carcinoma (NEECs) or type-II, consisting of distinct papillary serous and indistinct cell carcinomas [201]. In different types of endometrial cancers, the expression of endo-CBR (i.e., CB1 and CB2) has been specified. The expression of the $\mathrm{CB} 2$ receptor was identified using immunohistochemistry independently in the cells of endometrial cancer or endometrial tissues. $\mathrm{CB}_{2}$ protein expression was considerably increased in tissues of endometrial cancer as compared to healthy endometrial tissues. Moreover, the immunoblotting analysis showed that insignificant changes were prominent in $\mathrm{CB}_{1}$ expression.

Mass spectrometry findings indicated an insignificant increase in levels of AEA or PEA that suggested the 2-AG up-regulation in endometrial cancer tissues. Immunoblotting analysis showed the selective down-regulated expression of MAGL in endometrial cancer tissues as compared to normal tissues. However, there were minor differences in FAAH protein expression. The regulation mechanism of the $\mathrm{CB}_{2}$ receptor is changed in endometrial cancer because of a significant increase in the level of $\mathrm{CB}_{2}$ in the cell line of human endometrial carcinoma $\left(\mathrm{AN}_{3} \mathrm{CA}\right)$ compared to healthy cells. For the expression of endocannabinoid receptor $\mathrm{CB}_{2}$, both types of cells (i.e., $\mathrm{AN}_{3} \mathrm{CA}$ and healthy cells) were transfected with cDNA comprising plasmid [201,202]. Recent studies revealed the diversified endogenous pathway for $\mathrm{CB}_{2}$ in endometrial adenocarcinoma. In the etiology of endometrial cancer, the endogenous way for $\mathrm{CB}_{2}$ can be one of the fundamental factors primarily linked to the regulatory pathway of the ECS. In endometrial cancer tissues, the ultimate aspect for the growth of endometrial cancer is a significant increase in the expression of $\mathrm{CB}_{2}$ receptors and level of 2-AG. These changes resulted in a primary difference in the ratio of estrogen/progesterone; however, further studies are required to validate the observations. In $\mathrm{AN}_{3} \mathrm{CA}$ transfected cells, the effect of $\mathrm{CB}_{2}$ has been studied, and the mitochondrial function of the cell was reduced by $40 \%$ compared to healthy cells [205]. Such an effect could not enhance by using an agonist of the $\mathrm{CB}_{2}$ receptor, i.e., JWH133, although it is inhibited through the antagonist of the $\mathrm{CB}_{2}$ receptor, i.e., SR144528. A new diagnosis method for endometrial cancer can be the increased expression level of $\mathrm{CB}_{2}$ receptors, particularly in tumor-developing cells. Subsequently, specific $\mathrm{CB}_{2}$ agonists could facilitate the development of novel antitumor compounds to treat endometrial carcinoma because those compounds can eradicate cancer cells without any adverse effect [202]. There are discrepancies in the association of sex steroid hormone homeostasis and the ECS because it can enhance the growth rate of cancer cells, cell development, cell proliferation, and migration. Thus, for dynamic treatment purposes, the ECS has been considered a smart, innovative target in the initial period for pharmacological mediation in the fight against several hormone-related cancers.

\subsection{Melanoma}

Melanoma is mainly recognized as malignant cutaneous melanoma. It is a kind of skin cancer and the growing frequency of the highest mortality rate worldwide [206,207]. Such types of cancers can trace by great metastatic potential, enriched heterogeneity, and resistance to chemotherapy [208]. The availability of little groups of tumor cells known as melanoma initiating cells (MICs) is the critical aspect that is linked with failure treatment [209-212]. The ECS comprises endocannabinoid and their G-protein coupled receptors and enzymes responsible for their metabolism. The ECS performs a vital role in regulating signaling pathways involved in neoplastic transformation, tumor growth, and 
progression $[8,213]$. $\mathrm{CB}_{1}$ receptor modulation involves the administration of neurogenesis among the descent of neural crest melanoma cells and normal melanocytes [214].

In metastatic melanoma, usually, CNS is involved, and ECS may also perform function(s) in migration and tumor cell circulation in CNS [215]. It is suggested that AEA may induce cytotoxicity via triggering a caspase-dependent pathway in human melanoma cells $[131,216]$. In summary, the total cytotoxic effect of AEA occurs when a micro-molar range of concentrations is administrated and seems to be mediated through AEA byproducts of COX-2 and LOX metabolism.

\subsection{Basal Cell Carcinoma}

Keratinocytes are the predominant entity available in stratified squamous epithelium. The propagation and variation of keratinocytes are essentially regulated and coordinated. On the lower membrane, the basal keratinocytes are bonded and indistinguishable but possess the ability to proliferate. Keratinocytes escape from the cell cycle before the differentiation pathway and migrate towards the epidermis surface. The migration towards the epidermis directed the development of the external layer of the epidermis. The constantly shaded external layer consisted of enucleated dead squamous from the skin surface [217]. The occurrence rate of both benign and malignant skin neoplasms has been significantly increased over the last few years. Therefore, non-melanoma skin cancer is one of the more frequent malignancies in humans. Basal cell and squamous cell carcinomas exhibit the enormous identified prevalence of malignant tumors [217-220]. These types of cancers are primarily developed from the hair follicle stem cells $[218,221]$. However, their growth and proliferation depend on initial burst neovascularization [222,223], in which obligatory entities are VEGF (vascular endothelial growth factor) [217,224] and EGFR (epidermal growth factor receptor) $[218,222]$. Moreover, the skin is an essential point for internal metastasis disease $[217,218]$. Patients associated with this disease can be controlled using early-stage recognition, validation by the biopsy, and appropriate therapy selection. Recently, different approaches are being used as cancer treatment therapies. Cryotherapy, such as 5-fluorouracil, a topical chemotherapeutic agent and photodynamic, although the molecules reduced penetration into the skin and make it difficult to enter into all cancer cells/tissues [218].

This particular mechanism encouraged to find whether (i), the skin as well as skin cancers possess receptors of cannabinoids; (ii), in vivo, the activation of cannabinoid receptor utilizes a role of growth-inhibition on skin cancers; (iii), and lastly, angiogenesis inhibition is associated with the anti-tumoral effect of cannabinoids. These findings illustrate (i), the presence of both receptors $\left(\mathrm{CB}_{1}\right.$ and $\left.\mathrm{CB}_{2}\right)$ in the skin and skin cancer; (ii), in vivo activation of local cannabinoid receptor triggers the degeneration of skin tumors; (iii), and finally, tumor cells direct apoptosis and tumor angiogenesis inhibition mechanisms $[225,226]$.

Recent research in ER stress-apoptosis shows the potential function of oxidative stress and whether this factor is controlled through receptors such as $\mathrm{CB}_{1}, \mathrm{CB}_{2}$, or TRPV1. In non-melanoma skin cancer cells (NMSC), the increasing level of intracellular glutathione and induced oxidative stress are both restrained by AEA. Trolox was employed to calculate the oxidative stress-induced via AEA, antioxidants, $N$-acetylcysteine (NAC) among cell death [225-227]. All antioxidants improved the anti-proliferative effect of AEA. Besides, the expression of CHOP10 is induced by AEA, and the Trolox inhibits the action of caspase three. Therefore, oxidative stress is required for AEA-induced ER stress-apoptosis. On the other hand, $\mathrm{CB}_{1}, \mathrm{CB}_{2}$, and TRPV1 did not inhibit the AEA-induced oxidative stress or ER stress-apoptosis. The AEA-induced ER-stress apoptosis in cells of NMSC is performed through oxidative stress by adopting the receptor-independent mechanism. In the future, to exclude NMSC receptor-independent mechanism, AEA signaling pathways can be rigorously analyzed or investigated [228-230]. 


\subsection{Breast Cancer}

The most communal type of cancer is breast cancer in women [231,232]. Identifying possible aspects that participate in the development of breast cancer is genetically linked to childbearing, lacking in breastfeeding, increasing levels of the hormone(s), and the deficiency of iodine $[231,233,234]$. The second name of breast cancer is malignant breast neoplasm. Malignant breast neoplasm derives from breast tissue, frequently from the milk ducts (carcinomas of the duct)/the lobules (carcinoma of lobule). Malignant breast neoplasm cells can reach different body organs (e.g., bones, lungs, and lymph nodes) $[235,236]$. Currently, the ECs system's breast cancerfunction in regulatory pathways associated with tumor growth, induction of apoptosis, and administration of tumor vascularisation (angiogenesis) $[12,202,231]$. Angiogenesis is a process necessary for the transition of dormant state tumors to malignant state tumors $[237,238]$.

The expression of CBR has been identified in tissues or cell lines of various breast cancer. The $\mathrm{CB}_{1}$ expression was tested using immunohistochemistry, and the result showed $14 \%$ of tumors in human breast cancer found in tissues stating the epidermal growth factor (EGF) family member. This is stated as the ErbB2 tyrosine kinase receptor. There was no association recorded among the expression of ErbB2 and $\mathrm{CB}_{1}$ [239]. In $28 \%$ of human breast cancer cells, the $\mathrm{CB}_{1}$ immunoreactivity was also expressed [240]. Different cell lines (i.e., T-47D, MCF-7, TSA-E1, MDA-MB-231, and MDA-MB-468) of breast carcinoma possess the $\mathrm{CB}_{1}$ receptors. The presence of $\mathrm{CB}_{1}$ receptors in human breast tissues was identified using different techniques; e.g., immunofluorescence, RT-PCR (real time polymerase chain reaction), and western blot analysis [196,241]. However, $72 \%$ of tissue of human breast carcinoma showed $\mathrm{CB}_{2}$ immunoreactivity. Surprisingly, $\mathrm{CB}_{2}$ receptors were seen within $91 \%$ of ErbB2-positive carcinoma tissues, suggesting an association between the expression of $\mathrm{CB}_{2}$ and ErbB2. However, no association was observed between the expression of $\mathrm{CB}_{1}$ and ErbB2 [239]. Another study revealed the detection of immunoreactivity of $\mathrm{CB}_{2}$ receptors in 355 human breast tumor cells [240]. Moreover, $\mathrm{CB}_{2}$ receptors were also observed using the RT-PCR, immunofluorescence, and western blotting methods in different human breast cancer cell lines and/or tissues [239,242-245]. RT-PCR technique used to detect the recognized subtype GPR55 of cannabinoid receptor was significantly expressed in breast cancer cell line (i.e., MDA-MB-231). However, a 30-fold lower level expression was recorded in MCF-7 breast cancer cell lines [246]. The recognized endogenous ligands (known as lysophosphatidylinositol (LPI)) for GPR55 perform triggering functions for the migration of cells and invasion in the carcinoma cell line MDA-MB-231. Specific LPI effect on migration is inhibited with the pretreatment of cannabidiol (CBD) [246]. It is elaborated that LPI activates the proliferation, and this effect is inhibited through CBD. The presence of hydrolyzing enzyme (FAAH) of anandamide in EFM-19 and MCF-7 carcinoma cell lines was detected through northern blotting analysis [247] or RT-PCR techniques [248]. Nevertheless, the available data recommends that subtypes of multiple CBR and catalyzing enzymes required for the hydrolysis of endocannabinoid (i.e., FAAH) exhibit a functional circulation suitable to proliferation, migration, and apoptosis of breast carcinoma cell regulation.

In vitro findings showed that ECs and cannabinoids-like compounds restrained proliferation and migration or apoptosis induction in various breast cancer cell lines. In some carcinoma cell lines, phytocannabinoid CBD facilitate the inhibition of cell proliferation [249-252], increase apoptosis activity [249], and decrease migration [250,251]. The fundamental mechanism of CBD in inducing such effects requires further study. Although, the anti-proliferative characteristic is the part of $\Delta^{9}$-THC [253-255], whereas increased apoptosis [256] and migration of carcinoma cell are restrained [241,257,258]. Anti-proliferative and pro-apoptotic actions are induced through $\Delta^{9}$-THC associated with the $\mathrm{CB}_{2}$ receptor $[241,258,259]$.

In vitro studies show the anti-proliferative properties linked with ECs. Cell proliferation certainly blocks AEA $[253,260]$; however, not through $\mathrm{CB}_{2}$ receptors. Although $A E A$ and $C_{2}$ refereed effects may not be reduced, the individual study did not show their apparent. Furthermore, cell proliferation is blocked by 2-AG ole-amide, and arvanil, and their anti-proliferative effects are blocked by the $\mathrm{CB}_{1}$ (Figure 6) [253]. Remarkably, 
PEA that does not attach to CBR enhances the anti-proliferative effects of AEA, arvanil, olvanil and HU-210 [261], which is suggestive of a backup effect [262]. Additionally, AEA enhancement and the anti-proliferative effect of olvanil do not incorporate $\mathrm{CB}_{2}$ receptors. Methanandamide blocks both cell proliferation [261,263-265] and cell migration functions [264]. On the other hand, the mixture of a $\mathrm{CB}_{1}$ agonist $\left(\mathrm{WIN55,212-2)}\right.$ and $\mathrm{CB}_{2}$ agonist (JWH-133) blocks the proliferation and migration of each cell $[240,250]$. This blockage pathway requires activation of $\mathrm{CB}_{2}$ receptors, but no data is available for the possible action of $\mathrm{CB}_{1}$. Remarkably, both agonists CP55 940 and HU-210 of cannabinoid [253] and antagonists SR141716A of cannabinoid CB [266] showed the inhibition of cell proliferation. Amide derivatives such as $N$-palmitoyl tyrosine and $N$-palmitoyl dopamine possess anti-proliferative characteristics [267]. Cell proliferation is blocked by the cannabidiol acid, cannabigerol cannabichromene, THC acid [253,262,267], and desacetyl levonantradol [252] in different breast carcinoma cell lines.

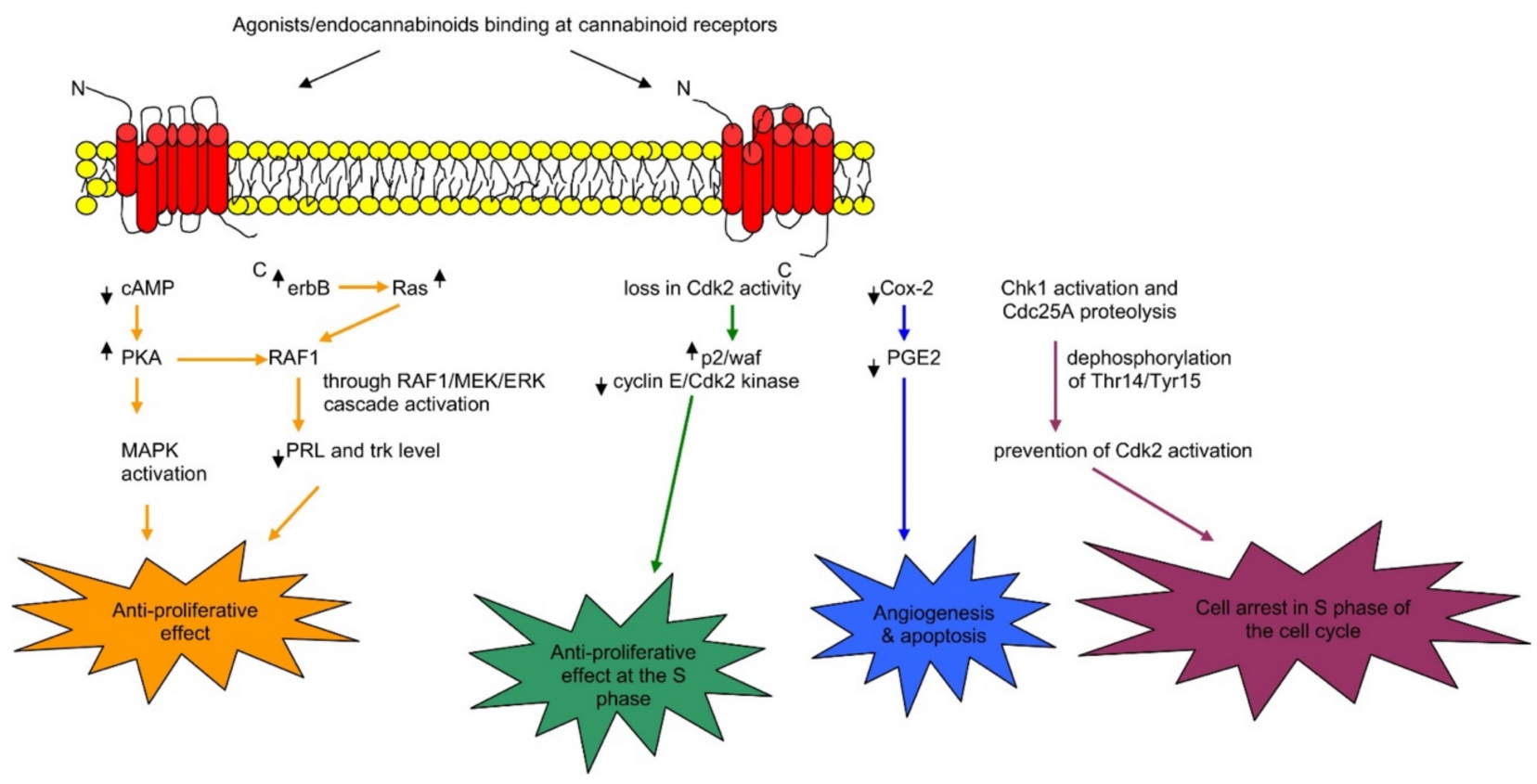

Figure 6. Schematic representation of examples of different pathways associated with anti-proliferative effects induced by cannabinoid receptor activation in breast cancer. Reprinted from Ref. [253] with permission from Elsevier. License Number: 5066110731347. Abbreviation: PKA (protein kinase A); cAMP (Cyclic adenosine monophosphate); MAPK (mitogen-activated protein kinase); Ras (rats sarcoma protein); Raf1 (proto-oncogene serine/threonine protein kinase); MEK (Mitogen-activated protein kinase); ERK (extracellular signal regulated kinase); PGE2 (prostaglandine E-2); TrK (tropomyosin receptor kinase); PRL (prolactin) COX-2 (cyclooxygenase-2); Cdk (cyclin-dependant kinase); Chk 1 (cell cycle checkpoint).

In vivo studies showed cannabinoids controlled the carcinoma growth, metastasis, cell proliferation, and angiogenesis determined using a mouse injected with various breast carcinomas cell lines. For instance, an animal model of metastatic breast cancer and metastases of the lung showed that $\Delta^{9}$-THC reduces the size, the number of cancer cells, and ErbB2 (tyrosine kinase receptor). Such cell proliferation inhibition involves the $\mathrm{CB}_{2}$ receptor but not the $\mathrm{CB}_{1}$ receptor [239]. The functions of $\mathrm{CB}_{2}$ receptors in anti-cancer properties are dependent on the $\mathrm{CB}_{2}$ agonist JWH-133 that can reduce carcinoma size and number $[239,240]$. Breast carcinoma cell proliferation is blocked through agonists of cannabinoids receptor of breast carcinoma cells via significant affinity nerve growth factor (Trk) and down-regulation of prolactin (PRL) receptors. Moreover, breast carcinoma susceptibility gene product (brca1) is down-regulated via the signaling pathways associated with CAMP-PKA/MAPK/Raf-ERK [268]. 


\subsection{Cannabinoids in Liver Cirrhosis}

In systemic or portal vasodilation and hypotension, $\mathrm{ECs}$ and $\mathrm{CB}_{1}$ receptors have been drawn in chronic liver cirrhosis $[269,270]$. The experimental data demonstrated that the $\mathrm{CB}_{1}$ receptor barrier, along with SR141716, overturned the hypotension and lowered the peripheral resistance. Moreover, the increased mesenteric flow of blood and portal pressure involve biliary, and carbon tetrachloride-induced cirrhosis is reduced among the rats. However, in non-cirrhotic administrated entities, these hemodynamic factors were modest through SR141716. Moreover, this data is specific and recommends an elevated endocannabinoid tendency in cirrhosis [270]. An elevated endocannabinoid tendency might support the up-regulation mechanism in $\mathrm{CB}_{1}$ receptors associated with hepatic vascular endothelial cells. This pathway may also facilitate the enhanced synthesis of anandamide through circulating monocytes. In the liver (from bile duct-ligated mice), elevated expression of $\mathrm{CB}_{1}$ receptors was recorded [271]. An elevated anandamide-induced vasorelaxation was exhibited in mesenteric arteries sequestered from cirrhotic of administered rats through $\mathrm{CB}_{1}$ and TRPV1 receptors [271,272]. The function of liver losses in cirrhosis due to the progressive elevation of endotoxin levels in plasma [271] is such an effect that is possibly associated with the increased synthesis of ECs among plasma monocytes, cirrhotic animals, and patients' platelets [270]. Current experimental results suggested improved signaling via myocardial $\mathrm{CB}_{1}$ receptors in the cirrhotic cardiomyopathy pathogenesis [270].

The ECS can also be associated with liver fibrosis pathogenesis after the end-stage cirrhosis vasculopathy. In vitro studies have currently identified that anandamide carries antifibrogenic effects by blocking stimulated hepatic stellate cells at low micromolar concentrations and their necrosis induction through $\mathrm{CB}_{1} / 2 \mathrm{TRPV}_{1}$-independent mechanism(s) at higher concentrations [273]. In the $\mathrm{CB}_{2}$ knockout mice model, the induction of carbon tetrachloride was much higher in liver fibrosis than their wild-type strain [270]. In liver biopsy samples from active cirrhosis patients, the expression of $\mathrm{CB}_{2}$ receptors was significantly induced [274]. Moreover, in myofibroblasts, activation of the $\mathrm{CB}_{2}$ receptor stimulates the inhibition of size and apoptosis. Thus, during chronic liver conditions, hepatic stellate cell activation emphasizes the antifibrogenic role of $\mathrm{CB}_{2}$ receptors. As anticipated from the above outcomes, the chronic practice of marijuana has been linked with hepatotoxicity relatively more than hepatoprotection [275]. Furthermore, current epidemiological study findings revealed that regular intake/smoking marijuana is a potential threat for fibrosis progression within chronic hepatitis $C$ infection patients [276]. The stimulated activation of the pro-fibrogenic role of the $\mathrm{CB}_{1}$ receptor is supported by the preliminary experimental work related to the development of liver fibrosis where carbon tetrachloride is triggered in mice $[277,278]$. These concluding results recommend the comprehensive role of $C_{1}$ receptors in cirrhosis pathogenesis and also suggest further possible remunerations from the therapeutic use of $\mathrm{CB}_{1}$ antagonists during chronic liver disease.

\section{Concluding Remarks}

Cannabinoids in numerous animal models' studies are active inflammatory modulators. Both in vivo and in vitro studies revealed an immunosuppressive effect of cannabinoids. However, further studies are required to carry out on human models. Biological and histological anti-inflammatory changes were tested in clinical trials of the following autoimmune diseases: multiple sclerosis, RA, scleroderma, and type-1 diabetes. In humans, autoimmune inflammatory bowel diseases, development of pain, positive influence on sleep, and improved life quality were explored. In ulcerative colitis, cannabinoid therapy reduced diarrhea conditions. Cannabinoids specific subtype: cannabidiol possesses less affinity towards both $\mathrm{CB}_{1}$ and $\mathrm{CB}_{2}$. Moreover, particularly synthetic cannabinoids show greater binding affinity to the $\mathrm{CB}_{2}$ receptor(s). They organize immunomodulatory effects lacking being psychoactive. Consequently, in research, they offer a possible therapeutic agent for autoimmune disorders. Nonetheless, cannabinoids are identified as potential candidates having numerous considerable antagonistic effects such as impairment of memory. Grey matter volume and reduction of IQ levels are both associated with THC. Few 
disorders related to psychology are also stimulated via THC. Due to the dopaminergic pathways, THC stimulation shows involvement in drug addiction, perhaps directed to dependence and drug abuse. Therefore, more research is required to illustrate how cannabinols would be utilized, their optimal concentrations, and which cannabinoids subtype should be more effective with less or no side effects.

Author Contributions: I.A., S.U.R., S.S., M.A.Z., M.A., M.M.S., Z.A., H.M.N.I. and Q.L. have equally contributed to conceptualization, literature analysis, and review drafting. All authors have read and agreed to the published version of the manuscript.

Funding: This work was supported by the National Natural Science Foundation of China (Grant No U20A2051 and 31860638), Guangxi Science and Technology Major Project of Guangxi (AB18221120 and AB18294046) and Guangxi Distinguished Scholar program.

Acknowledgments: Consejo Nacional de Ciencia y Tecnología (CONACYT) is thankfully acknowledged for partially supporting this work under the Sistema Nacional de Investigadores (SNI) program awarded to Hafiz M.N. Iqbal (CVU: 735340). The listed author(s) also expressed gratitude to their representative institutes and universities for providing access to the literature.

Conflicts of Interest: The authors declare no conflict of interest.

\section{References}

1. Morales, P.; Goya, P.; Jagerovic, N.; Hernandez-Folgado, L. Allosteric modulators of the CB1 cannabinoid receptor: A structural update review. Cannabis Cannabinoid Res. 2016, 1, 22-30. [CrossRef] [PubMed]

2. Glass, M.; Govindpani, K.; Furkert, D.P.; Hurst, D.P.; Reggio, P.H.; Flanagan, J.U. One for the price of two ... are bivalent ligands targeting cannabinoid receptor dimers capable of simultaneously binding to both receptors? Trends Pharmacol. Sci. 2016, 37, 353-363. [CrossRef] [PubMed]

3. Khan, M.I.; Soboci, A.; Czarnecka, A.; Król, M.; Botta, B.; Szczylik, C. The therapeutic aspects of the endocannabinoid system (ECS) for cancer and their development: From nature to laboratory. Curr. Pharm. Des. 2016, 22, 1756-1766. [CrossRef] [PubMed]

4. Tomko, A.M.; Whynot, E.G.; Ellis, L.D.; Dupré, D.J. Anti-cancer potential of cannabinoids, terpenes, and flavonoids present in cannabis. Cancers 2020, 12, 1985. [CrossRef] [PubMed]

5. Iannotti, F.A.; Di Marzo, V.; Petrosino, S. Endocannabinoids and endocannabinoid-related mediators: Targets, metabolism and role in neurological disorders. Prog. Lipid Res. 2016, 62, 107-128. [CrossRef]

6. Popp, J.R.; Petrakis, E.A.; Angelis, A.; Halabalaki, M.; Bonn, G.K.; Stuppner, H.; Skaltsounis, L.A. Rapid isolation of acidic cannabinoids from Cannabis sativa L. using pH-zone-refining centrifugal partition chromatography. J. Chromatogr. A 2019, 1599, 196-202. [CrossRef]

7. Atakan, Z. Cannabis, a complex plant: Different compounds and different effects on individuals. Ther. Adv. Psychopharmacol. 2012, 2, 241-254. [CrossRef]

8. Zou, S.; Kumar, U. Cannabinoid Receptors and the Endocannabinoid System: Signaling and Function in the Central Nervous System. Int. J. Mol. Sci. 2018, 19, 833.

9. Kalueff, A.V.; Stewart, A.M.; Song, C.; Berridge, K.C.; Graybiel, A.M.; Fentress, J.C. Neurobiology of rodent self-grooming and its value for translational neuroscience. Nat. Rev. Neurosci. 2016, 17, 45. [CrossRef]

10. Palmer, S.L.; Thakur, G.A.; Makriyannis, A. Cannabinergic ligands. Chem. Phys. Lipids 2002, 121, 3-19. [CrossRef]

11. Console-Bram, L.; Marcu, J.; Abood, M.E. Cannabinoid receptors: Nomenclature and pharmacological principles. Prog. Neuro Psychopharmacol. Biol. Psychiatry 2012, 38, 4-15. [CrossRef]

12. Moreno, E.; Cavic, M.; Krivokuca, A.; Casadó, V.; Canela, E. The Endocannabinoid System as a Target in Cancer Diseases: Are We There Yet? Front. Pharmacol. 2019, 10, 339. [CrossRef]

13. Boorman, E.; Zajkowska, Z.; Ahmed, R.; Pariante, C.M.; Zunszain, P.A. Crosstalk between endocannabinoid and immune systems: A potential dysregulation in depression? Psychopharmacology 2016, 233, 1591-1604. [CrossRef]

14. Bydalek, S. The Synthesis and Characterization of 2-Arachidonoyl Glycerol. Master's Thesis, University of Northern Colorado, Greeley, CO, USA, 2019.

15. Stensson, N. Endocannabinoids and Related Lipids in Chronic Pain: Analytical and Clinical Aspects. Ph.D. Thesis, Linköping University Electronic Press, Linköping, Sweden, 2018. [CrossRef]

16. Morell, C.; Bort, A.; Vara, D.; Ramos-Torres, A.; Rodriguez-Henche, N.; Diaz-Laviada, I. The cannabinoid WIN 55,212-2 prevents neuroendocrine differentiation of LNCaP prostate cancer cells. Prostate Cancer Prostatic Dis. 2016, 19, 248. [CrossRef]

17. Boroughs, L.K.; DeBerardinis, R.J. Metabolic pathways promoting cancer cell survival and growth. Nat. Cell Biol. 2015, 17, 351-359. [CrossRef]

18. Hansen, H.; Schmid, P.; Bittigau, P.; Lastres-Becker, I.; Berrendero, F.; Manzanares, J.; Ikonomidou, C.; Schmid, H.; Fernández-Ruiz, J.; Hansen, H. Anandamide, but not 2-arachidonylglycerol, accumulates during in vivo neurodegeneration. J. Neurochem. 2001, 78, 1415-1427. [CrossRef] 
19. Spruston, N.; Stuart, G.; Häusser, M. Principles of dendritic integration. Dendrites 2016, 351, 597.

20. Di Marzo, V.; Stella, N.; Zimmer, A. Endocannabinoid signalling and the deteriorating brain. Nat. Rev. Neurosci. $2015,16,30-42$. [CrossRef]

21. Soderstrom, K.; Soliman, E.; van Dross, R. Cannabinoids Modulate Neuronal Activity and Cancer by CB1 and CB2 ReceptorIndependent Mechanisms. Front. Pharmacol. 2019, 8, 20. [CrossRef]

22. Buser, G.L.; Gerona, R.R.; Horowitz, B.Z.; Vian, K.P.; Troxell, M.L.; Hendrickson, R.G.; Houghton, D.C.; Rozansky, D.; Su, S.W.; Leman, R.F. Acute kidney injury associated with smoking synthetic cannabinoid. Clin. Toxicol. 2014, 52, 664-673. [CrossRef]

23. Gatch, M.B.; Forster, M.J. $\Delta^{9}$-Tetrahydrocannabinol-like effects of novel synthetic cannabinoids found on the gray market. Behav. Pharmacol. 2015, 26, 460. [CrossRef]

24. Katchan, V.; David, P.; Shoenfeld, Y. Cannabinoids and autoimmune diseases: A systematic review. Autoimmun. Rev. 2016, 15, 513-528. [CrossRef]

25. Maroteaux, L.; Béchade, C.; Roumier, A. Dimers of serotonin receptors: Impact on ligand affinity and signaling. Biochimie 2019, 161, 23-33. [CrossRef]

26. de Oliveira, P.G.; Ramos, M.L.S.; Amaro, A.J.; Dias, R.A.; Vieira, S.I. Gi/o-Protein Coupled Receptors in the Aging Brain. Front. Aging Neurosci. 2019, 11. [CrossRef] [PubMed]

27. Slominski, A.T.; Li, W.; Kim, T.-K.; Semak, I.; Wang, J.; Zjawiony, J.K.; Tuckey, R.C. Novel activities of CYP11A1 and their potential physiological significance. J. Steroid Biochem. Mol. Biol. 2015, 151, 25-37. [CrossRef] [PubMed]

28. Lee, J.; Jung, M.; Park, H.; Kim, K.; Cho, D. Erdr1 suppresses murine melanoma growth via regulation of apoptosis. Int. J. Mol. Sci. 2016, 17, 107. [CrossRef] [PubMed]

29. Mecha, M.; Feliú, A.; Carrillo-Salinas, F.J.; Rueda-Zubiaurre, A.; Ortega-Gutiérrez, S.; de Sola, R.G.; Guaza, C. Endocannabinoids drive the acquisition of an alternative phenotype in microglia. Brain. Behav. Immun. 2015, 49, 233-245. [CrossRef]

30. Fraga, D.; Zanoni, C.I.S.; Zampronio, A.R.; Parada, C.A.; Rae, G.A.; Souza, G.E.P. Endocannabinoids, through opioids and prostaglandins, contribute to fever induced by key pyrogenic mediators. Brain. Behav. Immun. 2016, 51, 204-211. [CrossRef]

31. Li, X.; Peng, X.-Q.; Jordan, C.J.; Li, J.; Bi, G.-H.; He, Y.; Yang, H.-J.; Zhang, H.-Y.; Gardner, E.L.; Xi, Z.-X. mGluR5 antagonism inhibits cocaine reinforcement and relapse by elevation of extracellular glutamate in the nucleus accumbens via a CB1 receptor mechanism. Sci. Rep. 2018, 8. [CrossRef]

32. Abrams, D.I.; Guzman, M. Cannabis in cancer care. Clin. Pharmacol. Ther. 2015, 97, 575-586. [CrossRef]

33. Moranta Mesquida, D.; Esteban Valdés, S.C.; Garcia-Sevilla, J.A. Acute, chronic and withdrawal effects of the cannabinoid receptor agonist WIN55212-2 on the sequential activation of MAPK/Raf-MEK-ERK signaling in the rat cerebral frontal cortex: Short-term regulation by intrinsic and extrinsic pathways. J. Neurosci. Res. 2018, 85, 656-667. [CrossRef]

34. Alexandre, J.; Carmo, H.; Carvalho, F.; Silva, J.P. Synthetic cannabinoids and their impact on neurodevelopmental processes. Addict. Biol. 2019, 25, e12824. [CrossRef]

35. Kaya, M.C.; Bulut, M.; Kaplan, İ.; Gunes, M. Levels of endocannabinoid metabolizing enzymes are not related with BDNF levels in patients with schizophrenia: A case-controlled study. Psychiatry Clin. Psychopharmacol. 2018, 29, 441-445. [CrossRef]

36. Dempsey, S.K.; Gesseck, A.M.; Ahmad, A.; Daneva, Z.; Ritter, J.K.; Poklis, J.L. Formation of HETE-EAs and dihydroxy derivatives in mouse kidney tissue and analysis by high-performance liquid chromatography tandem mass spectrometry. J. Chromatogr. $B$ 2019, 1126, 121748. [CrossRef]

37. Iuvone, T.; Affaitati, G.; de Filippis, D.; Lopopolo, M.; Grassia, G.; Lapenna, D.; Negro, L.; Costantini, R.; Vaia, M.; Cipollone, F. Ultramicronized palmitoylethanolamide reduces viscerovisceral hyperalgesia in a rat model of endometriosis plus ureteral calculosis: Role of mast cells. Pain 2016, 157, 80-91. [CrossRef]

38. Gil-Ordóñez, A.; Martín-Fontecha, M.; Ortega-Gutiérrez, S.; López-Rodríguez, M.L. Monoacylglycerol lipase (MAGL) as a promising therapeutic target. Biochem. Pharmacol. 2018, 157, 18-32. [CrossRef]

39. Uhelski, M.L.; Khasabova, I.; Simone, D.A. Modulation of Pain by Endocannabinoids in the Periphery. In Recent Advances in Cannabinoid Research; IntechOpen: London, UK, 2018; Volume 13. [CrossRef]

40. Iversen, L. Cannabis and the brain. Brain 2003, 126, 1252-1270. [CrossRef]

41. Pertwee, R.G. Pharmacology of cannabinoid CB 1 and CB 2 receptors. Pharmacol. Ther. 1997, 74, 129-180. [CrossRef]

42. Pertwee, R.G. Pharmacological actions of cannabinoids. In Cannabinoids; Springer: Berlin/Heidelberg, Germany, $2005 ;$ pp. 1-51.

43. Pertwee, R.G.; Gibson, T.M.; Stevenson, L.A.; Ross, R.A.; Banner, W.K.; Saha, B.; Razdan, R.K.; Martin, B.R. O-1057, a potent water-soluble cannabinoid receptor agonist with antinociceptive properties. Br. J. Pharmacol. 2000, 129, 1577-1584. [CrossRef]

44. Zhang, M.W.; Ho, R. The cannabis dilemma: A review of its associated risks and clinical efficacy. J. Addict. 2015, 2015, 707596. [CrossRef]

45. Lötsch, J.; Weyer-Menkhoff, I.; Tegeder, I. Current evidence of cannabinoid-based analgesia obtained in preclinical and human experimental settings. Eur. J. Pain 2018, 22, 471-484. [CrossRef] [PubMed]

46. Lomazzo, E.; Bindila, L.; Remmers, F.; Lerner, R.; Schwitter, C.; Hoheisel, U.; Lutz, B. Therapeutic potential of inhibitors of endocannabinoid degradation for the treatment of stress-related hyperalgesia in an animal model of chronic pain. Neuropsychopharmacology 2015, 40, 488. [CrossRef] [PubMed]

47. Martín-Fontecha, M.; Angelina, A.; Rückert, B.; Rueda-Zubiaurre, A.; Martín-Cruz, L.; van de Veen, W.; Akdis, M.; OrtegaGutiérrez, S.; López-Rodríguez, M.L.; Akdis, C.A.; et al. A Fluorescent Probe to Unravel Functional Features of Cannabinoid Receptor CB1 in Human Blood and Tonsil Immune System Cells. Bioconjugate Chem. 2019, 29, 382-389. [CrossRef] [PubMed] 
48. Marsicano, G.; Moosmann, B.; Hermann, H.; Lutz, B.; Behl, C. Neuroprotective properties of cannabinoids against oxidative stress: Role of the cannabinoid receptor CB1. J. Neurochem. 2002, 80, 448-456. [CrossRef] [PubMed]

49. Puri, B.; Hall, A.; Ho, R. Revision Notes in Psychiatry; CRC Press: Boca Raton, FL, USA, 2013; ISBN 1444170147.

50. Piras, A.; Collin, L.; Grüninger, F.; Graff, C.; Rönnbäck, A. Autophagic and lysosomal defects in human tauopathies: Analysis of post-mortem brain from patients with familial Alzheimer disease, corticobasal degeneration and progressive supranuclear palsy. Acta Neuropathol. Commun. 2016, 4, 22. [CrossRef]

51. Khan, A.; Khan, S.; Kim, Y.S. Insight into Pain Modulation: Nociceptors Sensitization and Therapeutic Targets. Curr. Drug Targets 2019, 20, 775-788. [CrossRef]

52. Whiting, P.F.; Wolff, R.F.; Deshpande, S.; Di Nisio, M.; Duffy, S.; Hernandez, A.V.; Keurentjes, J.C.; Lang, S.; Misso, K.; Ryder, S. Cannabinoids for medical use: A systematic review and meta-analysis. JAMA 2015, 313, 2456-2473. [CrossRef]

53. Price, T.; Patwardhan, A.; Akopian, A.; Hargreaves, K.; Flores, C. Modulation of trigeminal sensory neuron activity by the dual cannabinoid-vanilloid agonists anandamide, $\mathrm{N}$-arachidonoyl-dopamine and arachidonyl-2-chloroethylamide. Br. J. Pharmacol. 2004, 141, 1118-1130. [CrossRef]

54. Smoum, R.; Baraghithy, S.; Chourasia, M.; Breuer, A.; Mussai, N.; Attar-Namdar, M.; Kogan, N.M.; Raphael, B.; Bolognini, D.; Cascio, M.G. CB2 cannabinoid receptor agonist enantiomers HU-433 and HU-308: An inverse relationship between binding affinity and biological potency. Proc. Natl. Acad. Sci. USA 2015, 112, 8774-8779. [CrossRef]

55. Cairns, E.A.; Toguri, J.T.; Porter, R.F.; Szczesniak, A.-M.; Kelly, M.E.M. Seeing over the horizon-targeting the endocannabinoid system for the treatment of ocular disease. J. Basic Clin. Physiol. Pharmacol. 2016, 27, 253-265. [CrossRef]

56. Palamar, J.J.; Acosta, P. Synthetic cannabinoid use in a nationally representative sample of US high school seniors. Drug Alcohol Depend. 2015, 149, 194-202. [CrossRef]

57. Viñals, X.; Moreno, E.; Lanfumey, L.; Cordomi, A.; Pastor, A.; De La Torre, R.; Gasperini, P.; Navarro, G.; Howell, L.A.; Pardo, L.; et al. Cognitive Impairment Induced by Delta9-tetrahydrocannabinol Occurs through Heteromers between Cannabinoid CB1 and Serotonin 5-HT2A Receptors. PLoS Biol. 2015, 13, e1002194. [CrossRef]

58. Shao, Z.; Yin, J.; Chapman, K.; Grzemska, M.; Clark, L.; Wang, J.; Rosenbaum, D.M. High-resolution crystal structure of the human CB1 cannabinoid receptor. Nature 2016, 540, 602-606. [CrossRef]

59. Ohno-Shosaku, T.; Matsui, M.; Fukudome, Y.; Shosaku, J.; Tsubokawa, H.; Taketo, M.; Manabe, T.; Kano, M. Postsynaptic M1 and M3 receptors are responsible for the muscarinic enhancement of retrograde endocannabinoid signalling in the hippocampus. Eur. J. Neurosci. 2003, 18, 109-116. [CrossRef]

60. Castaneto, M.S.; Wohlfarth, A.; Desrosiers, N.A.; Hartman, R.L.; Gorelick, D.A.; Huestis, M.A. Synthetic cannabinoids pharmacokinetics and detection methods in biological matrices. Drug Metab. Rev. 2015, 47, 124-174. [CrossRef]

61. Moldovan, R.P.; Teodoro, R.; Gao, Y.; Deuther-Conrad, W.; Kranz, M.; Wang, Y.; Kuwabara, H.; Nakano, M.; Valentine, H.; Fischer, S.; et al. Development of a High-Affinity PET Radioligand for Imaging Cannabinoid Subtype 2 Receptor. J. Med. Chem. 2016, 59, 7840-7855. [CrossRef]

62. Yohn, S.E.; Conn, P.J. Positive allosteric modulation of M1 and M4 muscarinic receptors as potential therapeutic treatments for schizophrenia. Neuropharmacology 2018, 136, 438-448. [CrossRef]

63. Gugliandolo, A.; Pollastro, F.; Grassi, G.; Bramanti, P.; Mazzon, E. In Vitro Model of Neuroinflammation: Efficacy of Cannabigerol, a Non-Psychoactive Cannabinoid. Int. J. Mol. Sci. 2018, 19, 1992. [CrossRef]

64. Kluger, B.; Triolo, P.; Jones, W.; Jankovic, J. The therapeutic potential of cannabinoids for movement disorders. Mov. Disord. 2015, 30, 313-327. [CrossRef]

65. Klegeris, A.; McGeer, P.L. Non-Steroidal Anti-Inflammatory Drugs (NSAIDs) and Other Anti- Inflammatory Agents in the Treatment of Neurodegenerative Disease. Curr. Alzheimer Res. 2005, 2, 355-365. [CrossRef]

66. Ge, Y.-T.; Zhong, A.-Q.; Xu, G.-F.; Lu, Y. Resveratrol protects BV2 mouse microglial cells against LPS-induced inflammatory injury by altering the miR-146a-5p/TRAF6/NF-kB axis. Immunopharmacol. Immunotoxicol. 2019, 41, 549-557. [CrossRef] [PubMed]

67. April, P.S.; Allen, A.; Sullivan, N.; Dampier, W.; Homan, G.; Kercher, K.; Passic, S.; Williams, J. Abstracts from the Joint Meeting of the International Society for NeuroVirology (ISNV) and the Society on NeuroImmune Pharmacology (SNIP) 10-14 April 2018, Chicago, IL, USA. J. Neurovirol. 2018, 24, 1-102. [CrossRef]

68. Reggio, P. Endocannabinoid Binding to the Cannabinoid Receptors: What Is Known and What Remains Unknown. Curr. Med. Chem. 2010, 17, 1468-1486. [CrossRef] [PubMed]

69. Kozela, E.; Pietr, M.; Juknat, A.; Rimmerman, N.; Levy, R.; Vogel, Z. Cannabinoids Delta(9)-tetrahydrocannabinol and cannabidiol differentially inhibit the lipopolysaccharide-activated NF- $\mathrm{B}$ and interferon-beta/STAT proinflammatory pathways in BV-2 microglial cells. J. Biol. Chem. 2010, 285, 1616-1626. [CrossRef]

70. Izzo, A.A.; Borrelli, F.; Capasso, R.; Di Marzo, V.; Mechoulam, R. Non-psychotropic plant cannabinoids: New therapeutic opportunities from an ancient herb. Trends Pharmacol. Sci. 2009, 30, 515-527. [CrossRef]

71. Devinsky, O.; Cilio, M.R.; Cross, H.; Fernandez-Ruiz, J.; French, J.; Hill, C.; Katz, R.; Di Marzo, V.; Jutras-Aswad, D.; Notcutt, W.G. Cannabidiol: Pharmacology and potential therapeutic role in epilepsy and other neuropsychiatric disorders. Epilepsia 2014, 55, 791-802. [CrossRef]

72. Hill, A.J.; Williams, C.M.; Whalley, B.J.; Stephens, G.J. Phytocannabinoids as novel therapeutic agents in CNS disorders. Pharmacol. Ther. 2012, 133, 79-97. [CrossRef] 
73. Tang, J.; Chen, Q.; Guo, J.; Yang, L.; Tao, Y.; Li, L.; Miao, H.; Feng, H.; Chen, Z.; Zhu, G. Minocycline Attenuates Neonatal Germinal-Matrix-Hemorrhage-Induced Neuroinflammation and Brain Edema by Activating Cannabinoid Receptor 2. Mol. Neurobiol. 2016, 53, 1935-1948. [CrossRef]

74. Kapur, S.; Pal, A. Immune Cell Activation: Stimulation, Costimulation, and Regulation of Cellular Activation. In Immune Response Activation Immunomodulation; Tyagi, S., Bisen, P.S., Eds.; IntechOpen: London, UK, 2018; Chapter 5; Available online: https:/ / www.intechopen.com/books/immune-response-activation-and-immunomodulation/immune-cell-activationstimulation-costimulation-and-regulation-of-cellular-activation (accessed on 20 May 2021). [CrossRef]

75. Majumder, M.M.; Leppä, M.; Hellesoy, M.; Dowling, P.; Malyutina, A.; Bazou, D.; Andersson, E.I.; Parsons, A.; Tang, J.; Kallioniemi, O.; et al. Multi-Parametric Single Cell Profiling Defines Distinct Drug Responses in Healthy Hematological Cell Lineages That Are Retained in Corresponding Malignant Cell Types. Blood 2018, 132, 264. [CrossRef]

76. Richard, A.C.; Lun, A.T.L.; Lau, W.W.Y.; Göttgens, B.; Marioni, J.C.; Griffiths, G.M. T cell cytolytic capacity is independent of initial stimulation strength. Nat. Immunol. 2018, 19, 849-858. [CrossRef]

77. Di Marzo, V. New approaches and challenges to targeting the endocannabinoid system. Nat. Rev. Drug Discov. 2018, 17, 623-639. [CrossRef]

78. Oláh, A.; Szekanecz, Z; Bíró, T. Targeting Cannabinoid Signaling in the Immune System: "High"-ly Exciting Questions, Possibilities, and Challenges. Front. Immunol. 2017, 8, 1487. [CrossRef]

79. Lopez-Rodriguez, A.B.; Acaz-Fonseca, E.; Giatti, S.; Caruso, D.; Viveros, M.P.; Melcangi, R.C.; Garcia-Segura, L.M. Correlation of brain levels of progesterone and dehydroepiandrosterone with neurological recovery after traumatic brain injury in female mice. Psychoneuroendocrinology 2015, 56, 1-11. [CrossRef]

80. Yuan, M.; Kiertscher, S.; Cheng, Q.; Zoumalan, R.; Tashkin, D.; Roth, M. Delta 9-Tetrahydrocannabinol regulates Th1/Th2 cytokine balance in activated human T cells. J. Neuroimmunol. 2003, 133, 124-131. [CrossRef]

81. Munro, S.; Thomas, K.L.; Abu-Shaar, M. Molecular characterization of a peripheral receptor for cannabinoids. Nat. Cell Biol. 1993, 365, 61-65. [CrossRef]

82. Thomas, B.F.; Gilliam, A.F.; Burch, D.F.; Roche, M.J.; Seltzman, H.H. Comparative receptor binding analyses of cannabinoid agonists and antagonists. J. Pharmacol. Exp. Ther. 1998, 285, 285-292.

83. Tang, J.; Tao, Y.; Jiang, B.; Chen, Q.; Hua, F.; Zhang, J.; Zhu, G.; Chen, Z. Pharmacological Preventions of Brain Injury Following Experimental Germinal Matrix Hemorrhage: An Up-to-Date Review. Transl. Stroke Res. 2016, 7, 20-32. [CrossRef]

84. Iffland, K.; Grotenhermen, F. An Update on Safety and Side Effects of Cannabidiol: A Review of Clinical Data and Relevant Animal Studies. Cannabis Cannabinoid Res. 2017, 2, 139-154. [CrossRef]

85. Nair, V.S.; Elkord, E. Immune checkpoint inhibitors in cancer therapy: A focus on T-regulatory cells. Immunol. Cell Biol. 2018, 96, 21-33. [CrossRef]

86. Eagar, T.N.; Miller, S.D. 16-Helper T-Cell Subsets and Control of the Inflammatory Response. In Clinical Immunology, 5th ed.; Rich, R.R., Fleisher, T.A., Shearer, W.T., Schroeder, H.W., Frew, A.J., Weyand, C.M., Eds.; Elsevier: London, UK, 2019; pp. 235-245. ISBN 978-0-7020-6896-6.

87. Rieder, S.A.; Chauhan, A.; Singh, U.; Nagarkatti, M.; Nagarkatti, P. Cannabinoid-induced apoptosis in immune cells as a pathway to immunosuppression. Immunobiology 2010, 215, 598-605. [CrossRef]

88. Maccarrone, M.; Lorenzon, T.; Bari, M.; Melino, G.; Finazzi-Agrò, A. Anandamide induces apoptosis in human cells via vanilloid receptors Evidence for a protective role of cannabinoid receptors. J. Biol. Chem. 2000, 275, 31938-31945. [CrossRef] [PubMed]

89. Schwarz, H.; Blanco, F.J.; Lotz, M. Anadamide, an endogenous cannabinoid receptor agonist inhibits lymphocyte proliferation and induces apoptosis. J. Neuroimmunol. 1994, 55, 107-115. [CrossRef]

90. dos-Santos-Pereira, M.; da-Silva, C.A.; Guimarães, F.S.; del-Bel, E. Co-administration of cannabidiol and capsazepine reduces L-DOPA-induced dyskinesia in mice: Possible mechanism of action. Neurobiol. Dis. 2016, 94, 179-195. [CrossRef] [PubMed]

91. Burstein, S. Cannabidiol (CBD) and its analogs: A review of their effects on inflammation. Bioorg. Med. Chem. 2015, 23, 1377-1385. [CrossRef]

92. Ölander, M.; Handin, N.; Artursson, P. Image-Based Quantification of Cell Debris as a Measure of Apoptosis. Anal. Chem. 2019, 91, 5548-5552. [CrossRef]

93. Silva, A.R.; Grosso, C.; Delerue-Matos, C.; Rocha, J.M. Comprehensive review on the interaction between natural compounds and brain receptors: Benefits and toxicity. Eur. J. Med. Chem. 2019, 174, 87-115. [CrossRef]

94. Hosseinzadeh, M.; Nikseresht, S.; Khodagholi, F.; Naderi, N.; Maghsoudi, N. Cannabidiol Post-Treatment Alleviates Rat EpilepticRelated Behaviors and Activates Hippocampal Cell Autophagy Pathway Along with Antioxidant Defense in Chronic Phase of Pilocarpine-Induced Seizure. J. Mol. Neurosci. 2016, 58, 432-440. [CrossRef]

95. Nichols, J.M.; Kaplan, B.L.F. Immune Responses Regulated by Cannabidiol. Cannabis Cannabinoid Res. 2019, 5, 12-31. [CrossRef]

96. Franco, R.; Fernández-Suárez, D. Alternatively activated microglia and macrophages in the central nervous system. Prog. Neurobiol. 2015, 131, 65-86. [CrossRef]

97. Turgeman, I.; Bar-Sela, G. Cannabis for cancer-Illusion or the tip of an iceberg: A review of the evidence for the use of Cannabis and synthetic cannabinoids in oncology. Expert Opin. Investig. Drugs 2019, 28, 285-296. [CrossRef]

98. Jain, K.K. Neuroprotection in Miscellaneous Neurological Disorders. In The Handbook of Neuroprotection; Jain, K.K., Ed.; Springer: New York, NY, USA, 2019; pp. 643-766. ISBN 978-1-4939-9465-6. 
99. D'Uva, G.; Baci, D.; Albini, A.; Noonan, D.M. Cancer chemoprevention revisited: Cytochrome P450 family $1 \mathrm{~B} 1$ as a target in the tumor and the microenvironment. Cancer Treat. Rev. 2018, 63, 1-18. [CrossRef]

100. Cruz, S.L.; Sánchez-Miranda, E.; Castillo-Arellano, J.I.; Cervantes-Villagrana, R.D.; Ibarra-Sánchez, A.; González-Espinosa, C. Anandamide inhibits FceRI-dependent degranulation and cytokine synthesis in mast cells through CB2 and GPR55 receptor activation. Possible involvement of CB2-GPR55 heteromers. Int. Immunopharmacol. 2018, 64, 298-307. [CrossRef]

101. Alfulaij, N.; Meiners, F.; Michalek, J.; Small-Howard, A.L.; Turner, H.C.; Stokes, A.J. Cannabinoids, the Heart of the Matter. J. Am. Heart Assoc. 2018, 7, e009099. [CrossRef]

102. Turcotte, D.; Doupe, M.; Torabi, M.; Gomori, A.; Ethans, K.; Esfahani, F.; Galloway, K.; Namaka, M. Nabilone as an adjunctive to gabapentin for multiple sclerosis-induced neuropathic pain: A randomized controlled trial. Pain Med. 2015, 16, 149-159. [CrossRef]

103. Koh, Y.-C.; Yang, G.; Lai, C.-S.; Weerawatanakorn, M.; Pan, M.-H. Chemopreventive Effects of Phytochemicals and Medicines on M1/M2 Polarized Macrophage Role in Inflammation-Related Diseases. Int. J. Mol. Sci. 2018, 19, 2208. [CrossRef]

104. Villarroya, F.; Cereijo, R.; Villarroya, J.; Gavaldà-Navarro, A.; Giralt, M. Toward an Understanding of How Immune Cells Control Brown and Beige Adipobiology. Cell Metab. 2018, 27, 954-961. [CrossRef]

105. Sexton, M.; Silvestroni, A.; Möller, T.; Stella, N. Differential migratory properties of monocytes isolated from human subjects naïve and non-naïve to Cannabis. Inflammopharmacology 2013, 21, 253-259. [CrossRef]

106. Hegde, V.L.; Hegde, S.; Cravatt, B.F.; Hofseth, L.J.; Nagarkatti, M.; Nagarkatti, P.S. Attenuation of experimental autoimmune hepatitis by exogenous and endogenous cannabinoids: Involvement of regulatory T cells. Mol. Pharmacol. 2008, 74, 20-33. [CrossRef]

107. Szutorisz, H.; Hurd, Y.L. Epigenetic effects of cannabis exposure. Biol. Psychiatry 2016, 79, 586-594. [CrossRef]

108. Liu, Y.; Chen, L.Y.; Zeng, H.; Ward, R.; Wu, N.; Ma, L.; Mu, X.; Li, Q.L.; Yang, Y.; An, S.; et al. Assessing the real-time activation of the cannabinoid CB1 receptor and the associated structural changes using a FRET biosensor. Int. J. Biochem. Cell Biol. 2019, 99, 114-124. [CrossRef]

109. Mona, E.; Eid, M.A. Effect of cannabinoid ingestion (in the form of bhang) on the immune system of high school and university students. Hum. Exp. Toxicol. 2004, 23, 149-156.

110. Rachelefsky, G.S.; Opelz, G.; Mickey, M.R.; Lessin, P.; Kiuchi, M.; Silverstein, M.J.; Stiehm, E.R. Intact humoral and cell-mediated immunity in chronic marijuana smoking. J. Allergy Clin. Immunol. 1976, 58, 483-490. [CrossRef]

111. Carrascal, L.; Nunez-Abades, P.; Ayala, A.; Cano, M. Role of Melatonin in the Inflammatory Process and its Therapeutic Potential. Curr. Pharm. Des. 2018, 24, 1563-1588. [CrossRef] [PubMed]

112. Samson, M.-T.; Small-Howard, A.; Shimoda, L.M.N.; Koblan-Huberson, M.; Stokes, A.J.; Turner, H. Differential roles of CB1 and CB2 cannabinoid receptors in mast cells. J. Immunol. 2003, 170, 4953-4962. [CrossRef]

113. Small-Howard, A.L.; Shimoda, L.M.N.; TURNER, H. Anti-inflammatory potential of CB1-mediated cAMP elevation in mast cells. Biochem. J. 2005, 388, 465-473. [CrossRef]

114. Wei, C.H.; Peng, Y.; Leaman, R.; Davis, A.P.; Mattingly, C.J.; Li, J.; Wiegers, T.C.; Lu, Z. Assessing the state of the art in biomedical relation extraction: Overview of the BioCreative V chemical-disease relation (CDR) task. Database 2016, 2016, baw032. [CrossRef]

115. Klein, T.W.; Newton, C.; Zhu, W.; Daaka, Y.; Friedman, H. $\Delta^{9}$-tetrahydrocannabinol, cytokines, and immunity to Legionella pneumophila. Exp. Biol. Med. 1995, 209, 205-212. [CrossRef]

116. Al-Ghezi, Z.Z.; Miranda, K.; Nagarkatti, M.; Nagarkatti, P.S. Combination of Cannabinoids, $\Delta^{9}$-Tetrahydrocannabinol and Cannabidiol, Ameliorates Experimental Multiple Sclerosis by Suppressing Neuroinflammation Through Regulation of miRNAMediated Signaling Pathways. Front. Immunol. 2019, 10, 1921. [CrossRef]

117. Rom, S.; Persidsky, Y. Cannabinoid receptor 2: Potential role in immunomodulation and neuroinflammation. J. Neuroimmune Pharmacol. 2013, 8, 608-620. [CrossRef]

118. Zolnik, B.S.; González-Fernández, Á.; Sadrieh, N.; Dobrovolskaia, M.A. Minireview: Nanoparticles and the immune system. Endocrinology 2010, 151, 458-465. [CrossRef]

119. Kozela, E.; Juknat, A.; Gao, F.; Kaushansky, N.; Coppola, G.; Vogel, Z. Pathways and gene networks mediating the regulatory effects of cannabidiol, a nonpsychoactive cannabinoid, in autoimmune T cells. J. Neuroinflamm. 2016, 13, 136. [CrossRef]

120. Battista, N.; Bari, M.; Maccarrone, M. Endocannabinoids and reproductive events in health and disease. In Endocannabinoids; Springer International Publishing: Cham, Switzerland, 2015; pp. 341-365. ISBN 9783319208251.

121. Fujiwara, M.; Egashira, N. New perspectives in the studies on endocannabinoid and cannabis: Abnormal behaviors associate with CB1 cannabinoid receptor and development of therapeutic application. J. Pharmacol. Sci. 2004, 96, 362-366. [CrossRef]

122. Jackson, S.J.; Pryce, G.; Diemel, L.T.; Cuzner, M.L.; Baker, D. Cannabinoid-receptor 1 null mice are susceptible to neurofilament damage and caspase 3 activation. Neuroscience 2005, 134, 261-268. [CrossRef]

123. Lan, D.; Popowicz, G.M.; Pavlidis, I.V.; Zhou, P.; Bornscheuer, U.T.; Wang, Y. Conversion of a Mono- and Diacylglycerol Lipase into a Triacylglycerol Lipase by Protein Engineering. ChemBioChem 2015, 16, 1431-1434. [CrossRef]

124. Ogasawara, D.; Deng, H.; Viader, A.; Baggelaar, M.P.; Breman, A.; den Dulk, H.; van den Nieuwendijk, A.M.C.H.; Soethoudt, M.; van der Wel, T.; Zhou, J.; et al. Rapid and profound rewiring of brain lipid signaling networks by acute diacylglycerol lipase inhibition. Proc. Natl. Acad. Sci. USA 2016, 113, 26-33. [CrossRef] 
125. Keller, J.L.; Fritz, N.; Chiang, C.C.; Jiang, A.; Thompson, T.; Cornet, N.; Newsome, S.D.; Calabresi, P.A.; Zackowski, K. Adapted resistance training improves strength in eight weeks in individuals with multiple sclerosis. J. Vis. Exp. 2016, 107, e53449. [CrossRef]

126. Belendiuk, K.A.; Baldini, L.L.; Bonn-Miller, M.O. Narrative review of the safety and efficacy of marijuana for the treatment of commonly state-approved medical and psychiatric disorders. Addict. Sci. Clin. Pract. 2015, 10. [CrossRef]

127. Eljaschewitsch, E.; Witting, A.; Mawrin, C.; Lee, T.; Schmidt, P.M.; Wolf, S.; Hoertnagl, H.; Raine, C.S.; Schneider-Stock, R.; Nitsch, $\mathrm{R}$. The endocannabinoid anandamide protects neurons during CNS inflammation by induction of MKP-1 in microglial cells. Neuron 2006, 49, 67-79. [CrossRef]

128. Shahrbanian, S.; Duquette, P.; Kuspinar, A.; Mayo, N.E. Contribution of symptom clusters to multiple sclerosis consequences. Qual. Life Res. 2015, 24, 617-629. [CrossRef]

129. Collin, C.; Davies, P.; Mutiboko, I.K.; Ratcliffe, S. Randomized controlled trial of cannabis-based medicine in spasticity caused by multiple sclerosis. Eur. J. Neurol. 2007, 14, 290-296. [CrossRef]

130. Ball, S.; Vickery, J.; Hobart, J.; Wright, D.; Green, C.; Shearer, J.; Nunn, A.; Cano, M.G.; MacManus, D.; Miller, D. The Cannabinoid Use in Progressive Inflammatory brain Disease (CUPID) trial: A randomised double-blind placebo-controlled parallel-group multicentre trial and economic evaluation of cannabinoids to slow progression in multiple sclerosis. Health Technol. Assess. 2015, 19, 7. [CrossRef] [PubMed]

131. Baron, E.P. Comprehensive Review of Medicinal Marijuana, Cannabinoids, and Therapeutic Implications in Medicine and Headache: What a Long Strange Trip It's Been ... . Headache J. Head Face Pain 2015, 55, 885-916. [CrossRef] [PubMed]

132. Xie, L.; Xie, H.; Chen, C.; Tao, Z.; Zhang, C.; Cai, L. Inhibiting the PI3K/AKT/NF-kB signal pathway with nobiletin for attenuating the development of osteoarthritis: In vitro and in vivo studies. Food Funct. 2019, 10, 2161-2175. [CrossRef] [PubMed]

133. TenBroek, E.M.; Yunker, L.; Nies, M.F.; Bendele, A.M. Randomized controlled studies on the efficacy of antiarthritic agents in inhibiting cartilage degeneration and pain associated with progression of osteoarthritis in the rat. Arthritis Res. Ther. 2016, 18, 24. [CrossRef]

134. Huang, T.-L.; Wu, C.-C.; Yu, J.; Sumi, S.; Yang, K.-C. 1-Lysine regulates tumor necrosis factor-alpha and matrix metalloproteinase-3 expression in human osteoarthritic chondrocytes. Process Biochem. 2016, 51, 904-911. [CrossRef]

135. Gui, H.; Tong, Q.; Qu, W.; Mao, C.-M.; Dai, S.-M. The endocannabinoid system and its therapeutic implications in rheumatoid arthritis. Int. Immunopharmacol. 2015, 26, 86-91. [CrossRef]

136. Barrie, N. Endocannabinoid-Based Nanoparticles Targeted to the Synovium for the Treatment of Arthritis. Ph.D. Thesis, University of Sydney, Sydney, Australia, 2019.

137. Dunn, S.L.; Wilkinson, J.M.; Crawford, A.; Bunning, R.A.D.; Le Maitre, C.L. Expression of Cannabinoid Receptors in Human Osteoarthritic Cartilage: Implications for Future Therapies. Cannabis Cannabinoid Res. 2016, 1, 3-15. [CrossRef]

138. O'Sullivan, S.E.; Kendall, D.A. Cannabinoid activation of peroxisome proliferator-activated receptors: Potential for modulation of inflammatory disease. Immunobiology 2010, 215, 611-616. [CrossRef]

139. Pertwee, R.G.; Howlett, A.C.; Abood, M.E.; Alexander, S.P.H.; Di Marzo, V.; Elphick, M.R.; Greasley, P.J.; Hansen, H.S.; Kunos, G.; Mackie, K. International Union of Basic and Clinical Pharmacology. LXXIX. Cannabinoid receptors and their ligands: Beyond CB1 and CB2. Pharmacol. Rev. 2010, 62, 588-631. [CrossRef]

140. Sun, Y.; Alexander, S.P.H.; Kendall, D.A.; Bennett, A.J. Cannabinoids and PPAR $\alpha$ signalling. Biochem. Soc. Trans. 2006, 34, 1095-1097. [CrossRef]

141. Reddy, D.S.; Golub, V.M. The pharmacological basis of cannabis therapy for epilepsy. J. Pharmacol. Exp. Ther. 2016, 357, 45-55. [CrossRef]

142. Dongiovanni, P.; Petta, S.; Maglio, C.; Fracanzani, A.L.; Pipitone, R.; Mozzi, E.; Motta, B.M.; Kaminska, D.; Rametta, R.; Grimaudo, S.; et al. Transmembrane 6 superfamily member 2 gene variant disentangles nonalcoholic steatohepatitis from cardiovascular disease. Hepatology 2015, 61, 506-514. [CrossRef]

143. Geurts, L.; Everard, A.; van Hul, M.; Essaghir, A.; Duparc, T.; Matamoros, S.; Plovier, H.; Castel, J.; Denis, R.G.P.; Bergiers, M.; et al. Adipose tissue NAPE-PLD controls fat mass development by altering the browning process and gut microbiota. Nat. Commun. 2015, 6, 6495. [CrossRef]

144. Wang, M.; Wang, C.; Han, X. Selection of internal standards for accurate quantification of complex lipid species in biological extracts by electrospray ionization mass spectrometry-What, how and why? Mass Spectrom. Rev. 2017, 36, 693-714. [CrossRef]

145. Peng, C.; Shi, Q.P.; Liu, J.Y.; Lv, Y.J.; Li, J.; Yi, L.; Bai, S.S.; Liu, L.; Wang, P.X.; Zhou, H.; et al. Alpha7 nAChR Expression Is Correlated with Arthritis Development and Inhibited by Sinomenine in Adjuvant-Induced Arthritic Rats. Evid. Based Complement. Altern. Med. 2019, 2019, 3759304. [CrossRef]

146. Gruden, G.; Barutta, F.; Kunos, G.; Pacher, P. Role of the endocannabinoid system in diabetes and diabetic complications. Br. J. Pharmacol. 2016, 173, 1116-1127. [CrossRef]

147. Hill, K.P.; Blanco, C.; Hasin, D.S.; Wall, M.M.; Flórez-Salamanca, L.; Hoertel, N.; Wang, S.; Kerridge, B.T.; Olfson, M. Cannabis use and risk of psychiatric disorders: Prospective evidence from a US national longitudinal study. JAMA J. Am. Med. Assoc. 2017, 73, 388-395.

148. Hohmann, A.; Suplita, R. Endocannabinoid mechanisms of pain modulation. AAPS J. 2006, 8, E693-E708. [CrossRef]

149. Schuelert, N.; McDougall, J.J. Cannabinoid-mediated antinociception is enhanced in rat osteoarthritic knees. Arthritis Rheum. 2008, 58, 145-153. [CrossRef] 
150. Richardson, D.; Pearson, R.G.; Kurian, N.; Latif, M.L.; Garle, M.J.; Barrett, D.A.; Kendall, D.A.; Scammell, B.E.; Reeve, A.J.; Chapman, V. Characterisation of the cannabinoid receptor system in synovial tissue and fluid in patients with osteoarthritis and rheumatoid arthritis. Arthritis Res. Ther. 2008, 10. [CrossRef]

151. Sagar, D.R.; Staniaszek, L.E.; Okine, B.N.; Woodhams, S.; Norris, L.M.; Pearson, R.G.; Garle, M.J.; Alexander, S.P.H.; Bennett, A.J.; Barrett, D.A. Tonic modulation of spinal hyperexcitability by the endocannabinoid receptor system in a rat model of osteoarthritis pain. Arthritis Rheum. 2010, 62, 3666-3676. [CrossRef] [PubMed]

152. Bryk, M.; Chwastek, J.; Kostrzewa, M.; Mlost, J.; Pedracka, A.; Starowicz, K. Alterations in anandamide synthesis and degradation during osteoarthritis progression in an animal model. Int. J. Mol. Sci. 2020, 21, 7381. [CrossRef] [PubMed]

153. Aso, E.; Ferrer, I. Cannabinoids for treatment of alzheimer's disease: Moving toward the clinic. Front. Pharmacol. 2014, 5, 37. [CrossRef] [PubMed]

154. Garcia-Gonzalez, E.; Selvi, E.; Balistreri, E.; Lorenzini, S.; Maggio, R.; Natale, M.-R.; Capecchi, P.-L.; Lazzerini, P.-E.; Bardelli, M.; Laghi-Pasini, F.; et al. Cannabinoids inhibit fibrogenesis in diffuse systemic sclerosis fibroblasts. Rheumatology 2009, 48, 1050-1056. [CrossRef]

155. Donvito, G.; Nass, S.R.; Wilkerson, J.L.; Curry, Z.A.; Schurman, L.D.; Kinsey, S.G.; Lichtman, A.H. The Endogenous Cannabinoid System: A Budding Source of Targets for Treating Inflammatory and Neuropathic Pain. Neuropsychopharmacology 2018, 43, 52-79. [CrossRef]

156. Laprairie, R.B.; Kulkarni, A.R.; Kulkarni, P.M.; Hurst, D.P.; Lynch, D.; Reggio, P.H.; Janero, D.R.; Pertwee, R.G.; Stevenson, L.A.; Kelly, M.E.M.; et al. Mapping Cannabinoid 1 Receptor Allosteric Site(s): Critical Molecular Determinant and Signaling Profile of GAT100, a Novel, Potent, and Irreversibly Binding Probe. ACS Chem. Neurosci. 2016, 7, 776-798. [CrossRef]

157. Vilela, L.R.; Gobira, P.H.; Viana, T.G.; Medeiros, D.C.; Ferreira-Vieira, T.H.; Doria, J.G.; Rodrigues, F.; Aguiar, D.C.; Pereira, G.S.; Massessini, A.R.; et al. Enhancement of endocannabinoid signaling protects against cocaine-induced neurotoxicity. Toxicol. Appl. Pharmacol. 2015, 286, 178-187. [CrossRef]

158. Garcia-Gonzalez, E.; Galeazzi, M.; Selvi, E. Can Cannabinoids Modulate Fibrotic Progression in Systemic Sclerosis? Isr. Med. Assoc. J. IMAJ 2016, 18, 156.

159. Ibeas Bih, C.; Chen, T.; Nunn, A.V.W.; Bazelot, M.; Dallas, M.; Whalley, B.J. Molecular Targets of Cannabidiol in Neurological Disorders. Neurotherapeutics 2015, 12, 699-730. [CrossRef]

160. Onos, K.D.; Sukoff Rizzo, S.J.; Howell, G.R.; Sasner, M. Toward more predictive genetic mouse models of Alzheimer's disease. Brain Res. Bull. 2016, 122, 1-11. [CrossRef]

161. Morena, M.; Patel, S.; Bains, J.S.; Hill, M.N. Neurobiological Interactions Between Stress and the Endocannabinoid System. Neuropsychopharmacology 2016, 122. [CrossRef]

162. Imam, S.; Prathibha, R.; Dar, P.; Almotah, K.; Al-Khudhair, A.; Hasan, S.A.-M.; Salim, N.; Jilani, T.N.; Mirmira, R.G.; Jaume, J.C. eIF5A inhibition influences T cell dynamics in the pancreatic microenvironment of the humanized mouse model of Type 1 Diabetes. Sci. Rep. 2019, 9. [CrossRef]

163. Pugliese, A. Insulitis in the pathogenesis of type 1 diabetes. Pediatr. Diabetes 2016, 17, 31-36. [CrossRef]

164. Swain, S.L. T-Cell Subsets: Who does the polarizing? Curr. Biol. 1995, 5, 849-851. [CrossRef]

165. Weiss, L.; Zeira, M.; Reich, S.; Har-Noy, M.; Mechoulam, R.; Slavin, S.; Gallily, R. Cannabidiol lowers incidence of diabetes in non-obese diabetic mice. Autoimmunity 2006, 39, 143-151. [CrossRef]

166. Nagarkatti, P.; Pandey, R.; Rieder, S.A.; Hegde, V.L.; Nagarkatti, M. Cannabinoids as novel anti-inflammatory drugs. Future Med. Chem. 2009, 1, 1333-1349. [CrossRef]

167. Mennella, I.; Savarese, M.; Ferracane, R.; Sacchi, R.; Vitaglione, P. Oleic acid content of a meal promotes oleoylethanolamide response and reduces subsequent energy intake in humans. Food Funct. 2015, 6, 203-209. [CrossRef]

168. Di Marzo, V.; Silvestri, C. Lifestyle and metabolic syndrome: Contribution of the endocannabinoidome. Nutrients 2019, 11, 1956. [CrossRef]

169. Lu, D.; Dopart, R.; Kendall, D.A. Controlled downregulation of the cannabinoid CB1 receptor provides a promising approach for the treatment of obesity and obesity-derived type 2 diabetes. Cell Stress Chaperones 2016, 21, 1-7. [CrossRef]

170. Francischetti, E.A.; de Abreu, V.G. The endocannabinoid system: A new perspective for cardiometabolic risk control. Arq. Bras. Cardiol. 2006, 87, 548-558. [CrossRef]

171. Piazza, P.V.; Cota, D.; Marsicano, G. The CB1 Receptor as the Cornerstone of Exostasis. Neuron 2017, 93, 1252-1274. [CrossRef] [PubMed]

172. Hirsch, S.; Tam, J. Cannabis: From a plant that modulates feeding behaviors toward developing selective inhibitors of the peripheral endocannabinoid system for the treatment of obesity and metabolic syndrome. Toxins 2019, 11, 275. [CrossRef] [PubMed]

173. Blüher, M.; Engeli, S.; Klöting, N.; Berndt, J.; Fasshauer, M.; Bátkai, S.; Pacher, P.; Schön, M.R.; Jordan, J.; Stumvoll, M. Dysregulation of the peripheral and adipose tissue endocannabinoid system in human abdominal obesity. Diabetes 2006, 55, 3053-3060. [CrossRef] [PubMed]

174. Borrelli, F.; Romano, B.; Petrosino, S.; Pagano, E.; Capasso, R.; Coppola, D.; Battista, G.; Orlando, P.; Di Marzo, V.; Izzo, A.A. Palmitoylethanolamide, a naturally occurring lipid, is an orally effective intestinal anti-inflammatory agent. Br. J. Pharmacol. 2015, 172, 142-158. [CrossRef] [PubMed] 
175. Sharma, C.; Sadek, B.; Goyal, S.N.; Sinha, S.; Kamal, M.A.; Ojha, S. Small Molecules from Nature Targeting G-Protein Coupled Cannabinoid Receptors: Potential Leads for Drug Discovery and Development. Evid. Based Complement. Alternat. Med. 2015, 2015, 238482. [CrossRef] [PubMed]

176. Higuera-Matas, A.; Ucha, M.; Ambrosio, E. Long-term consequences of perinatal and adolescent cannabinoid exposure on neural and psychological processes. Neurosci. Biobehav. Rev. 2015, 55, 119-146. [CrossRef]

177. Millan, M.J.; Andrieux, A.; Bartzokis, G.; Cadenhead, K.; Dazzan, P.; Fusar-Poli, P.; Gallinat, J.; Giedd, J.; Grayson, D.R.; Heinrichs, M.; et al. Altering the course of schizophrenia: Progress and perspectives. Nat. Rev. Drug Discov. 2016, 15, 485-515. [CrossRef]

178. Ambrose, T.; Simmons, A. Cannabis, Cannabinoids, and the Endocannabinoid System-Is there Therapeutic Potential for Inflammatory Bowel Disease? J. Crohns. Colitis 2019, 13, 525-535. [CrossRef]

179. Schicho, R.; Storr, M. Cannabis Finds Its Way into Treatment of Crohn's Disease. Pharmacology 2014, 93, 1-3. [CrossRef]

180. Kunos, G.; Pacher, P. Cannabinoids cool the intestine. Nat. Med. 2004, 10, 678-679. [CrossRef]

181. Alhouayek, M.; Muccioli, G. The endocannabinoid system in inflammatory bowel diseases: From pathophysiology to therapeutic opportunity. Trends Mol. Med. 2012, 18, 615-625. [CrossRef]

182. Sharkey, K.A.; Wiley, J.W. The Role of the Endocannabinoid System in the Brain—Gut Axis. Gastroenterology 2016, 151, 252-266. [CrossRef]

183. Izzo, A. The cannabinoid CB2 receptor: A good friend in the gut. Neurogastroenterol. Motil. 2007, 19, 704-708. [CrossRef]

184. Naftali, T.; Schleider, L.B.-L.; Dotan, I.; Lansky, E.P.; Benjaminov, F.S.; Konikoff, F.M. Cannabis induces a clinical response in patients with Crohn's disease: A prospective placebo-controlled study. Clin. Gastroenterol. Hepatol. 2013, 11, 1276-1280. [CrossRef]

185. Lal, S.; Prasad, N.; Ryan, M.; Tangri, S.; Silverberg, M.S.; Gordon, A.; Steinhart, H. Cannabis use amongst patients with inflammatory bowel disease. Eur. J. Gastroenterol. Hepatol. 2011, 23, 891-896. [CrossRef]

186. Naftali, T.; Mechulam, R.; Lev, L.B.; Konikoff, F.M. Cannabis for inflammatory bowel disease. Dig. Dis. 2014, 32, 468-474. [CrossRef]

187. Baker, D.; Pryce, G.; Giovannoni, G.; Thompson, A.J. The therapeutic potential of cannabis. Lancet Neurol. 2003, 2, 291-298. [CrossRef]

188. Lahat, A.; Lang, A.; Ben-Horin, S. Impact of cannabis treatment on the quality of life, weight and clinical disease activity in inflammatory bowel disease patients: A pilot prospective study. Digestion 2011, 85, 1-8. [CrossRef]

189. Shin, H.-J.; Hwang, K.-A.; Choi, K.-C. Antitumor Effect of Various Phytochemicals on Diverse Types of Thyroid Cancers. Nutrients 2019, 11, 125. [CrossRef]

190. Bulotta, S.; Capriglione, F.; Celano, M.; Pecce, V.; Russo, D.; Maggisano, V. Phytochemicals in thyroid cancer: Analysis of the preclinical studies. Endocrine 2021, 1-8. [CrossRef]

191. Velasco, G.; Hernández-Tiedra, S.; Dávila, D.; Lorente, M. The use of cannabinoids as anticancer agents. Prog. Neuro Psychopharmacol. Biol. Psychiatry 2016, 64, 259-266. [CrossRef] [PubMed]

192. Siddiqui, J.; Singh, A.; Chagtoo, M.; Singh, N.; Godbole, M.; Chakravarti, B. Phytochemicals for Breast Cancer Therapy: Current Status and Future Implications. Curr. Cancer Drug Targets 2015, 15, 116-135. [CrossRef] [PubMed]

193. Nikan, M.; Nabavi, S.M.; Manayi, A. Ligands for cannabinoid receptors, promising anticancer agents. Life Sci. 2016, 146, 124-130. [CrossRef] [PubMed]

194. Olmo, I.G.; Ferreira-Vieira, T.H.; Ribeiro, F.M. Dissecting the signaling pathways involved in the crosstalk between metabotropic glutamate 5 and cannabinoid type 1 receptors. Mol. Pharmacol. 2016, 90, 609-619. [CrossRef] [PubMed]

195. Sanchez, R.; Mercau, M.E.; Repetto, E.M.; Martinez Calejman, C.; Astort, F.; Perez, M.N.; Arias, P.; Cymeryng, C.B. Crosstalk between nitric oxide synthases and cyclooxygenase 2 in the adrenal cortex of rats under lipopolysaccharide treatment. Endocrine 2014, 46, 659-667. [CrossRef] [PubMed]

196. Ayakannu, T.; Taylor, A.H.; Marczylo, T.H.; Willets, J.M.; Konje, J.C. The Endocannabinoid System and Sex Steroid HormoneDependent Cancers. Int. J. Endocrinol. 2013, 2013, 259676. [CrossRef] [PubMed]

197. Maia, J.; Almada, M.; Silva, A.; Correia-da-Silva, G.; Teixeira, N.; Sá, S.I.; Fonseca, B.M. The endocannabinoid system expression in the female reproductive tract is modulated by estrogen. J. Steroid Biochem. Mol. Biol. 2017, 174, 40-47. [CrossRef]

198. Cui, N.; Wang, L.; Wang, W.; Zhang, J.; Xu, Y.; Jiang, L.; Hao, G. The correlation of anandamide with gonadotrophin and sex steroid hormones during the menstrual cycle. Iran. J. Basic Med. Sci. 2019, 20, 1268.

199. Amant, F.; Moerman, P.; Neven, P.; Timmerman, D.; van Limbergen, E.; Vergote, I. Endometrial cancer. Lancet 2005, 366, 491-505. [CrossRef]

200. Jemal, A.; Bray, F.; Center, M.M.; Ferlay, J.; Ward, E.; Forman, D. Global cancer statistics. CA Cancer J. Clin. 2011, 61, 69-90. [CrossRef]

201. Wasserman, E.; Tam, J.; Mechoulam, R.; Zimmer, A.; Maor, G.; Bab, I. CB1 cannabinoid receptors mediate endochondral skeletal growth attenuation by $\Delta^{9}$-tetrahydrocannabinol. Ann. N. Y. Acad. Sci. 2015, 1335, 110-119. [CrossRef]

202. Pyszniak, M.; Tabarkiewicz, J.; Łuszczki, J.J. Endocannabinoid system as a regulator of tumor cell malignancy-Biological pathways and clinical significance. Onco Targets Ther. 2016, 9, 4323-4336. [CrossRef]

203. Guan, J.; Xie, L.; Luo, X.; Yang, B.; Zhang, H.; Zhu, Q.; Chen, X. The prognostic significance of estrogen and progesterone receptors in grade I and II endometrioid endometrial adenocarcinoma: Hormone receptors in risk stratification. J. Gynecol. Oncol. 2019, 30. [CrossRef] 
204. Waqar, S.S.; Khan, S.A.; Sarfraz, T.; Waqar, S.S. Expression of Estrogen Receptors (ER), Progesterone Receptors (PR) and HER2/neu Receptors in Endometrial Carcinoma and Their Associations with Histological Types, Grades and Stages of the Tumor. Pak. J. Med. Sci. 2019, 34, 266-271. [CrossRef]

205. Guida, M.; Ligresti, A.; Filippis, D.; D’Amico, A.; Petrosino, S.; Cipriano, M.; Bifulco, G.; Simonetti, S.; Orlando, P.; Insabato, L.; et al. (PDF) The Levels of the Endocannabinoid Receptor CB2 and Its Ligand 2-Arachidonoylglycerol Are Elevated in Endometrial Carcinoma. Endocrinology 2019, 151, 921-928. [CrossRef]

206. Carpi, S.; Fogli, S.; Romanini, A.; Pellegrino, M.; Adinolfi, B.; Podestà, A.; Costa, B.; da Pozzo, E.; Martini, C.; Breschi, M.C.; et al. AM251 induces apoptosis and G2/M cell cycle arrest in A375 human melanoma cells. Anticancer Drugs 2015, 26, 754-762. [CrossRef]

207. Stobiecka, M.; Chalupa, A.; Dworakowska, B. Piezometric biosensors for anti-apoptotic protein survivin based on buried positive-potential barrier and immobilized monoclonal antibodies. Biosens. Bioelectron. 2016, 84, 37-43. [CrossRef]

208. Santini, R.; Pietrobono, S.; Pandolfi, S.; Montagnani, V.; D’amico, M.; Penachioni, J.Y.; Vinci, M.C.; Borgognoni, L.; Stecca, B. SOX2 regulates self-renewal and tumorigenicity of human melanoma-initiating cells. Oncogene 2014, 33, 4697-4708. [CrossRef]

209. Chen, F.; Zhuang, X.; Lin, L.; Yu, P.; Wang, Y.; Shi, Y.; Hu, G.; Sun, Y. New horizons in tumor microenvironment biology: Challenges and opportunities. BMC Med. 2015, 13. [CrossRef]

210. Kryza, T.; Silva, M.L.; Loessner, D.; Heuzé-Vourc'h, N.; Clements, J.A. The kallikrein-related peptidase family: Dysregulation and functions during cancer progression. Biochimie 2016, 122, 283-299. [CrossRef]

211. Tuccitto, A.; Castelli, C.; Alison, M.R.; Perego, M. Cancer Stem Cell Challenges in Melanoma Characterization and Treatment. In Cancer Stem Cell Resistance to Targeted Therapy; Maccalli, C., Todaro, M., Ferrone, S., Eds.; Resistance to Targeted Anti-Cancer Therapeutics; Springer International Publishing: Cham, Switzerland, 2019; pp. 115-135. ISBN 978-3-030-16624-3.

212. Rajayi, H.; Tavasolian, P.; Rezalotfi, A.; Ebrahimi, M. Cancer Stem Cells Targeting; the Lessons from the Interaction of the Immune System, the Cancer Stem Cells and the Tumor Niche. Int. Rev. Immunol. 2019, 38, 267-283. [CrossRef] [PubMed]

213. Pisanti, S.; Picardi, P.; D'Alessandro, A.; Laezza, C.; Bifulco, M. The endocannabinoid signaling system in cancer. Trends Pharmacol. Sci. 2013, 34, 273-282. [CrossRef] [PubMed]

214. Compagnucci, C.; Di Siena, S.; Bustamante, M.B.; Di Giacomo, D.; Di Tommaso, M.; Maccarrone, M.; Grimaldi, P.; Sette, C. Type-1 (CB 1) Cannabinoid Receptor Promotes Neuronal Differentiation and Maturation of Neural Stem Cells. PLoS ONE 2013, 8, e54271. [CrossRef] [PubMed]

215. Boiko, A.D.; Razorenova, O.V.; van de Rijn, M.; Swetter, S.M.; Johnson, D.L.; Ly, D.P.; Butler, P.D.; Yang, G.P.; Joshua, B.; Kaplan, M.J. Human melanoma-initiating cells express neural crest nerve growth factor receptor CD271. Nature 2011, 470, 424. [CrossRef]

216. Russo, E.B. Clinical Endocannabinoid Deficiency Reconsidered: Current Research Supports the Theory in Migraine, Fibromyalgia, Irritable Bowel, and Other Treatment-Resistant Syndromes. Cannabis Cannabinoid Res. 2016, 1, 154-165. [CrossRef]

217. Befort, K. Interactions of the opioid and cannabinoid systems in reward: Insights from knockout studies. Front. Pharmacol. 2015, 6, 6. [CrossRef]

218. Didovic, S.; Opitz, F.V.; Holzmann, B.; Förster, I.; Weighardt, H. Requirement of MyD88 signaling in keratinocytes for Langerhans cell migration and initiation of atopic dermatitis-like symptoms in mice. Eur. J. Immunol. 2016, 46, 981-992. [CrossRef]

219. Xu, Y.G.; Aylward, J.L.; Swanson, A.M.; Spiegelman, V.S.; Vanness, E.R.; Teng, J.M.C.; Snow, S.N.; Wood, G.S. 67-Nonmelanoma Skin Cancers: Basal Cell and Squamous Cell Carcinomas. In Abeloff's Clinical Oncology, 6th ed.; Niederhuber, J.E., Armitage, J.O., Kastan, M.B., Doroshow, J.H., Tepper, J.E., Eds.; Content Repository Only: Philadelphia, PA, USA, 2020; pp. 1052-1073. ISBN 978-0-323-47674-4.

220. Cooper, J.; Giancotti, F.G. Integrin Signaling in Cancer: Mechanotransduction, Stemness, Epithelial Plasticity, and Therapeutic Resistance. Cancer Cell 2019, 35, 347-367. [CrossRef]

221. Quist, S.R.; Eckardt, M.; Kriesche, A.; Gollnick, H.P. Expression of potential dermal progenitor cell markers in the tumour and stroma of skin adnexal malignant and benign tumours. Stem Cells Int. 2019, 2019, 9320701. [CrossRef]

222. Porcheri, C.; Meisel, C.T.; Mitsiadis, T. Multifactorial Contribution of Notch Signaling in Head and Neck Squamous Cell Carcinoma. Int. J. Mol. Sci. 2019, 20, 1520. [CrossRef]

223. Kutlubay, Z.; Engin, B.; Serdaroğlu, S.; Tüzün, Y. Current Management of Malignant Melanoma: State of the Art; IntechOpen: London, UK, 2019; Volume 1, p. 13.

224. Chien, C.Y.; Su, C.Y.; Hwang, C.F.; Chuang, H.C.; Hsiao, Y.C.; Wu, S.L.; Huang, C.C. Clinicopathologic significance of CD105 expression in squamous cell carcinoma of the hypopharynx. Head Neck 2006, 28, 441-446. [CrossRef]

225. Chiurchiu, V.; Battistini, L.; Maccarrone, M. Endocannabinoid signalling in innate and adaptive immunity. Immunology 2015, 144, 352-364. [CrossRef]

226. Zendulka, O.; Dovrtělová, G.; Nosková, K.; Turjap, M.; Šulcová, A.; Hanuš, L.; Juřica, J. Cannabinoids and Cytochrome P450 Interactions. Curr. Drug Metab. 2016, 17, 206-226. [CrossRef]

227. Wondrak, G.T. Let the sun shine in: Mechanisms and potential for therapeutics in skin photodamage. Curr. Opin. Investig. Drugs 2019, 8, 390-400.

228. Caterina, M.J. TRP channel cannabinoid receptors in skin sensation, homeostasis, and inflammation. ACS Chem. Neurosci. 2014, 5, 1107-1116. [CrossRef] 
229. Yesilyurt, O.; Cayirli, M.; Sakin, Y.S.; Seyrek, M.; Akar, A.; Dogrul, A. Systemic and spinal administration of FAAH, MAGL inhibitors and dual FAAH/MAGL inhibitors produce antipruritic effect in mice. Arch. Dermatol. Res. 2016, 308, 335-345. [CrossRef]

230. Soliman, E.; van Dross, R. Anandamide-induced endoplasmic reticulum stress and apoptosis are mediated by oxidative stress in non-melanoma skin cancer: Receptor-independent endocannabinoid signaling. Mol. Carcinog. 2016, 55, 1807-1821. [CrossRef]

231. Jové, M.; Gatius, S.; Yeramian, A.; Portero-Otin, M.; Eritja, N.; Santacana, M.; Colas, E.; Ruiz, M.; Pamplona, R.; Matias-Guiu, $\mathrm{X}$. Metabotyping human endometrioid endometrial adenocarcinoma reveals an implication of endocannabinoid metabolism. Oncotarget 2016, 7, 52364-52374. [CrossRef]

232. Torres, D.; Lorenzo Bermejo, J.; Garcia Mesa, K.; Gilbert, M.; Briceño, I.; Pohl-Zeidler, S.; González Silos, R.; Boekstegers, F.; Plass, C.; Hamann, U. Interaction between genetic ancestry and common breast cancer susceptibility variants in Colombian women. Int. J. Cancer 2019, 144, 2181-2191. [CrossRef]

233. Eastman, C.J.; Ma, G.; Li, M. Optimal Assessment and Quantification of Iodine Nutrition in Pregnancy and Lactation: Laboratory and Clinical Methods, Controversies and Future Directions. Nutrients 2019, 11, 2378. [CrossRef]

234. Waugh, D.T. Fluoride Exposure Induces Inhibition of Sodium/Iodide Symporter (NIS) Contributing to Impaired Iodine Absorption and Iodine Deficiency: Molecular Mechanisms of Inhibition and Implications for Public Health. Int. J. Environ. Res. Public Health 2019, 16, 1086. [CrossRef] [PubMed]

235. Fowler, C.J. Delta9-tetrahydrocannabinol and cannabidiol as potential curative agents for cancer: A critical examination of the preclinical literature. Clin. Pharmacol. Ther. 2015, 97, 587-596. [CrossRef]

236. Ligresti, A.; de Petrocellis, L.; Di Marzo, V. From phytocannabinoids to cannabinoid receptors and endocannabinoids: Pleiotropic physiological and pathological roles through complex pharmacology. Physiol. Rev. 2016, 96, 1593-1659. [CrossRef] [PubMed]

237. Fontana, F.; Liu, D.; Hirvonen, J.; Santos, H.A. Delivery of therapeutics with nanoparticles: What's new in cancer immunotherapy? Wiley Interdiscip. Rev. Nanomed. Nanobiotechnol. 2017, 9, e1421. [CrossRef] [PubMed]

238. Zheng, X.; Li, M.; Zhang, G. Tumor Dormancy and Angiogenesis-Dependent Progression. In Early-Stage Lung Cancer: Screening and Management; Zheng, X., Li, M., Zhang, G., Eds.; Springer: Singapore, 2018; pp. 103-123. ISBN 978-981-10-7596-4.

239. Caffarel, M.M.; Andradas, C.; Mira, E.; Pérez-Gómez, E.; Cerutti, C.; Moreno-Bueno, G.; Flores, J.M.; García-Real, I.; Palacios, J.; Mañes, S. Cannabinoids reduce ErbB2-driven breast cancer progression through Akt inhibition. Mol. Cancer 2010, 9, 196. [CrossRef] [PubMed]

240. Qamri, Z.; Preet, A.; Nasser, M.W.; Bass, C.E.; Leone, G.; Barsky, S.H.; Ganju, R.K. Synthetic cannabinoid receptor agonists inhibit tumor growth and metastasis of breast cancer. Mol. Cancer Ther. 2009, 8, 3117-3129. [CrossRef] [PubMed]

241. Chakravarti, B.; Ravi, J.; Ganju, R.K. Cannabinoids as therapeutic agents in cancer: Current status and future implications. Oncotarget 2014, 5, 5852-5872. [CrossRef]

242. Caffarel, M.M.; Sarrió, D.; Palacios, J.; Guzmán, M.; Sánchez, C. $\Delta^{9}$-tetrahydrocannabinol inhibits cell cycle progression in human breast cancer cells through Cdc2 regulation. Cancer Res. 2006, 66, 6615-6621. [CrossRef]

243. Di Marzo, V.; Goparaju, S.K.; Wang, L.; Liu, J.; Bátkai, S.; Járai, Z.; Fezza, F.; Miura, G.I.; Palmiter, R.D.; Sugiura, T. Leptin-regulated endocannabinoids are involved in maintaining food intake. Nature 2001, 410, 822-825. [CrossRef]

244. McKallip, R.J.; Nagarkatti, M.; Nagarkatti, P.S. $\Delta{ }^{-}{ }^{9}$-tetrahydrocannabinol enhances breast cancer growth and metastasis by suppression of the antitumor immune response. J. Immunol. 2005, 174, 3281-3289. [CrossRef]

245. Melck, D.; de Petrocellis, L.; Orlando, P.; Bisogno, T.; Laezza, C.; Bifulco, M.; Di Marzo, V. Suppression of Nerve Growth Factor Trk Receptors and Prolactin Receptors by Endocannabinoids Leads to Inhibition of Human Breast and Prostate Cancer Cell Proliferation 1. Endocrinology 2000, 141, 118-126. [CrossRef]

246. Ford, L.A.; Roelofs, A.J.; Anavi-Goffer, S.; Mowat, L.; Simpson, D.G.; Irving, A.J.; Rogers, M.J.; Rajnicek, A.M.; Ross, R.A. A role for L- $\alpha$-lysophosphatidylinositol and GPR55 in the modulation of migration, orientation and polarization of human breast cancer cells. Br. J. Pharmacol. 2010, 160, 762-771. [CrossRef]

247. Bisogno, T.; Katayama, K.; Melck, D.; Ueda, N.; de Petrocellis, L.; Yamamoto, S.; Di Marzo, V. Biosynthesis and degradation of bioactive fatty acid amides in human breast cancer and rat pheochromocytoma cells. Eur. J. Biochem. 1998, 254, 634-642. [CrossRef]

248. Takeda, S.; Yamaori, S.; Motoya, E.; Matsunaga, T.; Kimura, T.; Yamamoto, I.; Watanabe, K. $\Delta^{9}$-Tetrahydrocannabinol enhances MCF-7 cell proliferation via cannabinoid receptor-independent signaling. Toxicology 2008, 245, 141-146. [CrossRef]

249. Ligresti, A.; Moriello, A.S.; Starowicz, K.; Matias, I.; Pisanti, S.; de Petrocellis, L.; Laezza, C.; Portella, G.; Bifulco, M.; Di Marzo, V. Antitumor activity of plant cannabinoids with emphasis on the effect of cannabidiol on human breast carcinoma. J. Pharmacol. Exp. Ther. 2006, 318, 1375-1387. [CrossRef]

250. McAllister, S.D.; Christian, R.T.; Horowitz, M.P.; Garcia, A.; Desprez, P.-Y. Cannabidiol as a novel inhibitor of Id-1 gene expression in aggressive breast cancer cells. Mol. Cancer Ther. 2007, 6, 2921-2927. [CrossRef]

251. McAllister, S.D.; Murase, R.; Christian, R.T.; Lau, D.; Zielinski, A.J.; Allison, J.; Almanza, C.; Pakdel, A.; Lee, J.; Limbad, C. Pathways mediating the effects of cannabidiol on the reduction of breast cancer cell proliferation, invasion, and metastasis. Breast Cancer Res. Treat. 2011, 129, 37-47. [CrossRef]

252. Ruh, M.F.; Taylor, J.A.; Howlett, A.C.; Welshons, W.V. Failure of cannabinoid compounds to stimulate estrogen receptors. Biochem. Pharmacol. 1997, 53, 35-41. [CrossRef]

253. Javid, F.A.; Phillips, R.M.; Afshinjavid, S.; Verde, R.; Ligresti, A. Cannabinoid pharmacology in cancer research: A new hope for cancer patients? Eur. J. Pharmacol. 2016, 775. [CrossRef] 
254. Roy, H. A Review on Potential Role of Cannabinoids as Therapeutic Agents in Different Types of Cancer; BRAC University: Dhaka, Bangladesh, 2018.

255. Ballan, E.; Grinberg, M. Novel System and Method for Microbiome Profiling and Modulation by Means of Cannabis Administration. U.S. Patent Application 16/182,726, 9 May 2019.

256. Śledziński, P.; Zeyland, J.; Słomski, R.; Nowak, A. The current state and future perspectives of cannabinoids in cancer biology. Cancer Med. 2018, 7, 765-775. [CrossRef]

257. Takeda, S.; Okajima, S.; Miyoshi, H.; Yoshida, K.; Okamoto, Y.; Okada, T.; Amamoto, T.; Watanabe, K.; Omiecinski, C.; Aramaki, H. Cannabidiolic acid, a major cannabinoid in fiber-type cannabis, is an inhibitor of MDA-MB-231 breast cancer cell migration. Toxicol. Lett. 2012, 214, 314-319. [CrossRef] [PubMed]

258. Morales, P.; Jagerovic, N. Antitumor cannabinoid chemotypes: Structural insights. Front. Pharmacol. 2019, 10, 621. [CrossRef] [PubMed]

259. Capozzi, A.; Mattei, V.; Martellucci, S.; Manganelli, V.; Saccomanni, G.; Garofalo, T.; Sorice, M.; Manera, C.; Misasi, R. Antiproliferative properties and proapoptotic function of new CB2 selective cannabinoid receptor agonist in Jurkat leukemia cells. Int. J. Mol. Sci. 2019, 19, 1958. [CrossRef] [PubMed]

260. Brown, I.; Lee, J.; Sneddon, A.A.; Cascio, M.G.; Pertwee, R.G.; Wahle, K.W.J.; Rotondo, D.; Heys, S.D. Anticancer effects of n-3 EPA and DHA and their endocannabinoid derivatives on breast cancer cell growth and invasion. Prostaglandins Leukot. Essent. Fat. Acids 2020, 156, 102024. [CrossRef]

261. de Petrocellis, L.; Bisogno, T.; Ligresti, A.; Bifulco, M.; Melck, D.; Di Marzo, V. Effect on cancer cell proliferation of palmitoylethanolamide, a fatty acid amide interacting with both the cannabinoid and vanilloid signalling systems. Fundam. Clin. Pharmacol. 2002, 16, 297-302. [CrossRef]

262. Dando, I.; Donadelli, M.; Costanzo, C.; Dalla Pozza, E.; D’alessandro, A.; Zolla, L.; Palmieri, M. Cannabinoids inhibit energetic metabolism and induce AMPK-dependent autophagy in pancreatic cancer cells. Cell Death Dis. 2013, 4, e664. [CrossRef]

263. de Petrocellis, L.; Melck, D.; Palmisano, A.; Bisogno, T.; Laezza, C.; Bifulco, M.; Di Marzo, V. The endogenous cannabinoid anandamide inhibits human breast cancer cell proliferation. Proc. Natl. Acad. Sci. USA 1998, 95, 8375-8380. [CrossRef]

264. Grimaldi, C.; Pisanti, S.; Laezza, C.; Malfitano, A.M.; Santoro, A.; Vitale, M.; Caruso, M.G.; Notarnicola, M.; Iacuzzo, I.; Portella, G. Anandamide inhibits adhesion and migration of breast cancer cells. Exp. Cell Res. 2006, 312, 363-373. [CrossRef]

265. Laezza, C.; Malfitano, A.M.; Proto, M.C.; Esposito, I.; Gazzerro, P.; Formisano, P.; Pisanti, S.; Santoro, A.; Caruso, M.G.; Bifulco, M. Inhibition of 3-hydroxy-3-methylglutaryl-coenzyme A reductase activity and of Ras farnesylation mediate antitumor effects of anandamide in human breast cancer cells. Endocr. Relat. Cancer 2010, 17, 495-503. [CrossRef]

266. Dong, C.; Chen, J.; Harrington, A.; Vinod, K.Y.; Hegde, M.L.; Hegde, V.L. Cannabinoid exposure during pregnancy and its impact on immune function. Cell. Mol. Life Sci. 2019, 76, 729-743. [CrossRef]

267. Kisková, T.; Mungenast, F.; Suváková, M.; Jäger, W.; Thalhammer, T. Future Aspects for Cannabinoids in Breast Cancer Therapy. Int. J. Mol. Sci. 2019, 20, 1673. [CrossRef]

268. Robichaux, W.G.; Cheng, X. Intracellular cAMP Sensor EPAC: Physiology, Pathophysiology, and Therapeutics Development. Physiol. Rev. 2018, 98, 919-1053. [CrossRef]

269. Howes, O.D.; Murray, R.M. Schizophrenia: An integrated sociodevelopmental-cognitive model. Lancet 2014, 383 , 1677-1687. [CrossRef]

270. Sershen, H.; Hashim, A.; Dunlop, D.S.; Suckow, R.F.; Cooper, T.B.; Javitt, D.C. Modulating NMDA receptor function with d-amino acid oxidase inhibitors: Understanding functional activity in PCP-treated mouse model. Neurochem. Res. 2016, 41, 398-408. [CrossRef]

271. Wang, X.; Derakhshandeh, R.; Liu, J.; Narayan, S.; Nabavizadeh, P.; Le, S.; Danforth, O.M.; Pinnamaneni, K.; Rodriguez, H.J.; Luu, E.; et al. One Minute of Marijuana Secondhand Smoke Exposure Substantially Impairs Vascular Endothelial Function. J. Am. Heart Assoc. 2016, 5, e003858. [CrossRef]

272. Thomas, G.; Kloner, R.A.; Rezkalla, S. Adverse cardiovascular, cerebrovascular, and peripheral vascular effects of marijuana inhalation: What cardiologists need to know. Am. J. Cardiol. 2014, 113, 187-190. [CrossRef]

273. Dibba, P.; Li, A.A.; Cholankeril, G.; Iqbal, U.; Gadiparthi, C.; Khan, M.A.; Kim, D.; Ahmed, A. The Role of Cannabinoids in the Setting of Cirrhosis. Medicines 2018, 5, 52. [CrossRef]

274. Julien, B.; Grenard, P.; Teixeira-Clerc, F.; van Nhieu, J.T.; Li, L.; Karsak, M.; Zimmer, A.; Mallat, A.; Lotersztajn, S. Antifibrogenic role of the cannabinoid receptor CB2 in the liver. Gastroenterology 2005, 128, 742-755. [CrossRef]

275. Borini, P.; Guimarães, R.C.; Borini, S.B. Possible hepatotoxicity of chronic marijuana usage. Sao Paulo Med. J. 2004, 122, 110-116. [CrossRef]

276. Hézode, C.; Roudot-Thoraval, F.; Nguyen, S.; Grenard, P.; Julien, B.; Zafrani, E.; Pawlostky, J.; Dhumeaux, D.; Lotersztajn, S.; Mallat, A. Daily cannabis smoking as a risk factor for progression of fibrosis in chronic hepatitis C. Hepatology 2005, 42, 63-71. [CrossRef]

277. O'Keefe, L.; Simcocks, A.C.; Hryciw, D.H.; Mathai, M.L.; Mcainch, A.J. The cannabinoid receptor 1 and its role in influencing peripheral metabolism. Diabetes Obes. Metab. 2014, 16, 294-304. [CrossRef]

278. Lowin, T.; Pongratz, G.; Straub, R.H. The synthetic cannabinoid WIN55,212-2 mesylate decreases the production of inflammatory mediators in rheumatoid arthritis synovial fibroblasts by activating CB2, TRPV1, TRPA1 and yet unidentified receptor targets. $J$. Inflamm. 2016, 13, 15. [CrossRef] 